\title{
A history of the roles of cytochrome P450 enzymes in the toxicity of drugs
}

\author{
F. Peter Guengerich ${ }^{1}$ (D)
}

Received: 22 May 2020 / Revised: 22 May 2020 / Accepted: 11 June 2020 / Published online: 18 August 2020

(c) Korean Society of Toxicology 2020

\begin{abstract}
The history of drug metabolism began in the 19th Century and developed slowly. In the mid-20th Century the relationship between drug metabolism and toxicity became appreciated, and the roles of cytochrome P450 (P450) enzymes began to be defined in the 1960s. Today we understand much about the metabolism of drugs and many aspects of safety assessment in the context of a relatively small number of human P450s. P450s affect drug toxicity mainly by either reducing exposure to the parent molecule or, in some cases, by converting the drug into a toxic entity. Some of the factors involved are enzyme induction, enzyme inhibition (both reversible and irreversible), and pharmacogenetics. Issues related to drug toxicity include drug-drug interactions, drug-food interactions, and the roles of chemical moieties of drug candidates in drug discovery and development. The maturation of the field of P450 and drug toxicity has been facilitated by advances in analytical chemistry, computational capability, biochemistry and enzymology, and molecular and cell biology. Problems still arise with P450s and drug toxicity in drug discovery and development, and in the pharmaceutical industry the interaction of scientists in medicinal chemistry, drug metabolism, and safety assessment is critical for success.
\end{abstract}

Keywords Cytochrome P450 - Drugs · Toxicity $\cdot$ Reactive intermediates $\cdot$ Drug-drug interactions $\cdot$ Toxicophores

\section{Introduction}

Much has been written about cytochrome P450 (P450, CYP). In this review I will deal with one aspect of P450, drug toxicity, and the history of how this developed. Metabolism will be discussed in the context of causing (or preventing) toxicity, aside from drug efficacy per se.

I have attempted to do this from a historical background, for a reason. I am not sure that all of the younger scientists in the field appreciate the history or the lessons learned, and they can be important. I did not enter this research area until 1973, so everything discussed before that is what I have gleaned directly from others or from the literature. During the early days of my career I always seemed to be one of the

Electronic supplementary material The online version of this article (https://doi.org/10.1007/s43188-020-00056-z) contains supplementary material, which is available to authorized users.

F. Peter Guengerich

f.guengerich@vanderbilt.edu

1 Department of Biochemistry, Vanderbilt University School of Medicine, 638B Robinson Research Building, 2200 Pierce Avenue, Nashville, TN 37232-0146, USA younger members of the P450 field but now I find myself one of the older ones, as others retire and start disappearing. I would like to share some thoughts about the P450 field, focused on drug toxicity, from my own perspective.

Suffice it to say that the story of the application of P450 research to the development of new drugs, over the past 50 years, has been a remarkable success story. In part because of this, the number of drugs recalled by the Food and Drug Administration (FDA) in the United States has not been high, and apparently none have been approved that have proven to cause cancer or birth defects. There is still opportunity for improvement, as discussed at the end of this article.

Two major themes will appear in this historical perspective on the relationship of P450s with toxicity. One will be that $\mathrm{P} 450$ s prevent drug toxicity by oxidizing a drug to prevent its toxic effects. The opposite side will involve $\mathrm{P} 450$-catalyzed conversion of drugs to reactive products that cause toxicity (Fig. 1, Table 1). Over the top of these two over-arching themes will be effects of enzyme inhibition, induction, and other matters related to drug-drug interactions (Table 2). 


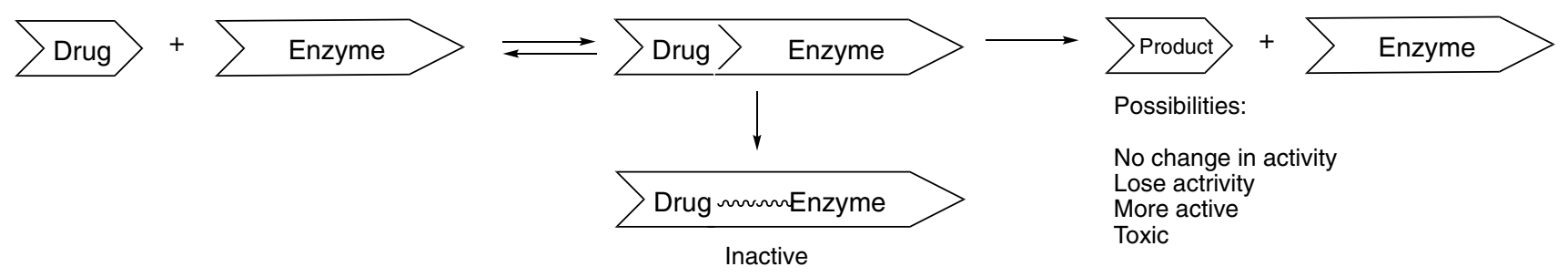

Fig. 1 General paradigm of drug metabolism and bioactivation by P450 enzymes

Table 1 Drugs with black box warnings for hepatotoxicity [1]

\begin{tabular}{lll}
\hline Drug & Dose $(\mathrm{mg} /$ day $)$ & Reactive products \\
\hline Acitretin & $25-50$ & No \\
Bosentau & $125-250$ & No \\
Dacarbazine & $140-315$ & Yes \\
Dantrolene & $300-400$ & Yes \\
Felbamate & 1200 & Yes \\
Flutamide & 750 & Yes \\
Gemtuzumab & $\left(9 \mathrm{mg} \mathrm{m}^{-3}\right)$ & Yes \\
Isoniazid & 300 & Yes \\
Ketoconazole & 200 & Yes \\
Naltrexone & 50 & No \\
Nevirapine & 200 & Yes \\
Tolcapone & 300 & Yes \\
Trovafloxacin & $100-500$ & No \\
Valproic acid & $1000-2400$ & Yes \\
& & $10 / 14=71 \%$ \\
\hline
\end{tabular}

\section{Early history of drug metabolism}

Although the field of toxicology can trace its roots back to ancient Greece and to Paracelsus 500 years ago [2], the appreciation of metabolism is more recent [3]. synthesis of urea [3] was a link between chemistry and physiology, and a number of studies on the metabolism of xenobiotics followed. These early studies were essentially all with simple organic chemicals administered to animals-or humans (including Wöhler and other scientists themselves)—such as benzene, benzoic acid, and cinnamic acid. The pioneering work by Baumann, Jaffe, von Mening, Schmiedeberg,
Thierfelder, Ure, Naunyn, Nencki, Keller, Erdmann, Marchand, and others primarily involved conjugations [4, 5]. Research on simple chemicals continued into the first half of the twentieth century and was still focused on conjugation reactions, even in the early work of Williams in the United Kingdom [4, 6-9].

One can ask why there was only limited investigation of the fates of drugs then. One of the main reasons is that there were really few drugs then, compared to today. Organic chemistry was developing, and there was only limited thought given to the fates of drugs and also very little to chronic side effects. Analytical chemistry was primitive by today's standards. As indicated by most of the subjects of [9] book Detoxication Mechanisms [9], drug metabolism was only beginning to emerge. However, scientists did realize that these enzymatic reactions seen with simple organic chemicals also occurred with actual drug molecules, both natural products and purely synthetic ones. By 1958 Brodie et al. [10] had described a number of in vitro oxidation reactions including deamination, $\mathrm{N}$-dealkylation, $\mathrm{O}$-dealkylation, sulfoxidation, and hydroxylation of alkyl groups and aromatic rings. These were usually observed with liver microsomes and were dependent upon NADPH (then abbreviated TPNH) and $\mathrm{O}_{2}$. At this time differences among animal species were recognized, as well as sex differences and inhibition by other drugs (e.g., SKF525A).

Another line of research first reported in the 1950s developed from reports by Remmer and his associates that administration of drugs to patients could accelerate the clearance of other drugs $[11,12]$. Further, a barbiturate could accelerate its own disappearance upon repeated administration. These studies, along with those of James and Elizabeth Miller and their student Allan Conney [13], were among
Table 2 Mechanisms of P450related drug-drug interactions

\begin{tabular}{ll}
\hline Perpetrator drug & Effect on victim drug \\
\hline Inducer & Increased metabolism, lack of efficacy \\
Inducer & Increased bioactivation via a minor pathway \\
Competitive inhibitor & Decreased metabolism, toxicity due to elevated level of drug \\
Irreversible inhibitor & Decreased metabolism, toxicity due to elevated level of drug \\
Allosteric activator & Same as inducer \\
\hline
\end{tabular}


the first to show induction of drug metabolism by xenobiotic chemicals.

\section{The discovery of P450}

By 1960 pharmaceutical scientists had begun to appreciate the role of drug metabolism, and most of the research was focused on in vivo work with pre-clinical animal models. However, basic in vitro research could now be done. Where was $\mathrm{P} 450$ in all of this?

Reports of spectra we now recognize as $\mathrm{P} 450$ had appeared in the late 1950s [14, 15]. However, these spectra were not really characterized, and the 1962 report by Ryo Sato and his student Tsuneo Omura [16] is generally considered the discovery of P450 (termed "pigment 450" because of the unusual wavelength maximum at $450 \mathrm{~nm}$ for the Soret band). This original report was followed by two more detailed 1964 papers by Omura and Sato $[17,18]$. The association of this spectral entity with NADPH-dependent hydroxylation was reported by Cooper, Rosenthal, and Estabrook [19] with bovine adrenal microsomes and what today is known as the $\mathrm{P} 45021 \mathrm{~A} 2$ reaction, steroid 21-hydroxylation.

\section{Important drugs and toxicity: thalidomde and acetaminophen}

At this point I will go back chronologically to a drug that has set many of the regulatory standards for today. Thalidomide was developed by a German company, Chemie-Grünenthal, in 1957 for treatment of morning sickness (nausea) in pregnant women. It was used in over 46 countries between 1957 and 1961 but was never approved by the United States FDA, although apparently some did enter the country. Thalidomide caused $>10,000$ severe birth defects, particularly abnormal limbs and also eye and ear problems, peripheral neuropathies, and damaged organ defects (intestinal tract, heart, lungs, and kidneys) [20]. It was withdrawn from the market in 1961.

This was a tragic case. Why did this happen? The compound had not caused teratogenic effects in rats. The major problem was species differences. It was later shown to cause defects in rabbits and primates, as well as humans. The difference in toxicity is somehow due to metabolism, as shown subsequently by Williams' group [21, 22] and later by Gordon et al. [23].

The fear of approving a drug that could cause birth defects or cancer has dominated US FDA policy to this day. Species differences are very much appreciated after this lesson with such an unfortunate outcome. If there is a "silver lining", this incident was what really opened the field of biochemical/mechanistic toxicology and provided the resources needed to study new drugs.

Some developments have occurred with thalidomide since then. Many hypotheses (at least 30) have been advanced to explain the species-specific teratogenesis. Thalidomide is not mutagenic. It is oxidized by $\mathrm{P} 450 \mathrm{~s}$ (2C19, 3A4, 3A5) to reactive epoxides and quinones that bind to glutathione and proteins (Fig. 2) [24-28], although the rates of oxidation are very slow. Thalidomide also produces reactive oxygen species [29], which might be synergistic with other damage. One proposed mechanism of damage involves binding to the protein cereblon [30] although the concentrations used in these experiments $(300 \mu \mathrm{M})$ may be too high to be relevant, in that a typical $C_{\mathrm{p}, \max }$ value (maximum plasma concentration) for thalidomide is $\sim 4 \mu \mathrm{M}$. In recent years thalidomide has had a revival in that it was approved for use in treating erythema nodosum leprosum (leprosy) in 1998 and multiple myeloma in 2006, and a derivative (lenalidomide) has gone on to be a successful drug for treating myeloma.

Acetaminophen (paracetamol, Tylenol ${ }^{\circledR}$ ) is a simple compound (4-hydroxyacetanilide) that was shown to be derived from oxidation of two earlier analgesics, phenacetin and acetanilide. It is used widely in the United States and Europe, with an estimated $23 \%$ of the population using it therapeutically at least once a week [31]. However, high doses are toxic, and this drug accounts for one-half of druginduced liver failures [31]. It is a classic example of Paracelsus's axiom "the dose makes the poison" (differentiating a medicine from a poison) [2].

A classic series of four back-to-back papers from the group of Brodie, Gillette, and Mitchell in 1973 showed that acetaminophen was bioactivated to a form that binds covalently to proteins [32-35]. In this series of papers, radioactive acetaminophen was shown to bind covalently to proteins in vitro and in vivo. Indices of toxicity were correlated with the extent of covalent binding. Subsequent work a number of years later implicated human P450s 2E1, 1A2, and 3A4 in the bioactivation [36], and knocking out P450 2e1 and1a2 in mice rendered the animals highly protected from acetaminophen poisoning $[37,38]$. Nelson's laboratory showed that 2-electron oxidation of acetaminophen to the iminoquinone is involved in the bioactivation process [39, 40] (Fig. 3). Many adducted proteins have been identified [41], but it is not clear that a single one is responsible for the toxicity. The meta congener of acetaminophen (3-hydroxyacetanilide) is less toxic, at least in some animal models, which may be related to its ability to form ortho-quinones but not the iminoquinone [42]. 


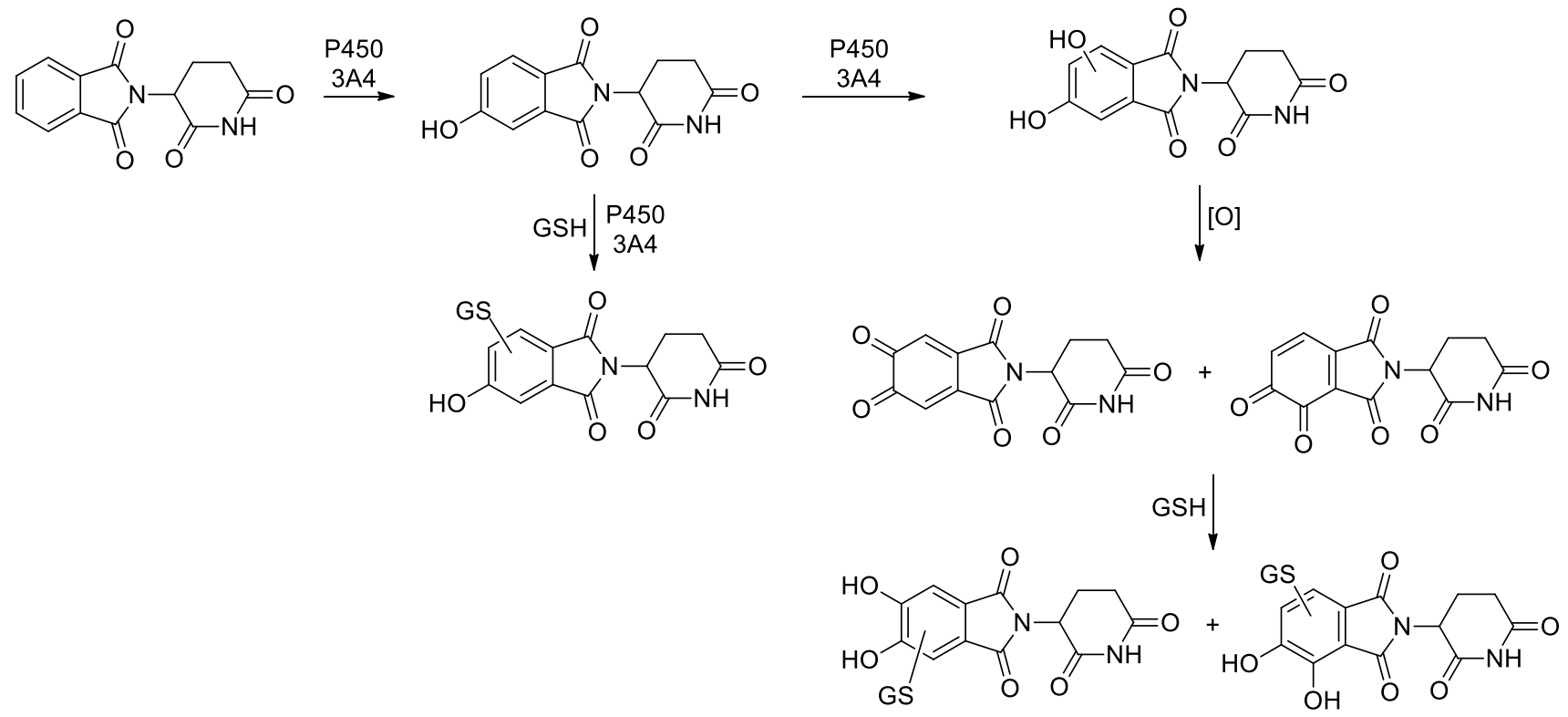

Fig. 2 Bioactivation of thalidomide [28]. Reprinted with permission from American Chemical Society. G. Chowdhury, N. Maryana, Y. Okada, Y. Uno, M. Shimizu, N. Shibata, F. P. Guengerich, and H. Yamazaki, Chemical Research in Toxicology 23, 1018-1024, 2010

Fig. 3 Bioactivation of acetaminophen<smiles>CC(=O)Nc1ccc(OC(C)=O)cc1NC(C)=O</smiles>

The "downstream" biological events involved in

acetaminophen toxicity are still unclear [43]. Genes implicated in mouse genetic studies [44] have not been replicated in human genetic studies [45]. Nevertheless, the roles of 
P450s in initiation of the damage are quite clear from the Gonzalez mouse studies [37, 38].

\section{More developments in the 1970s}

The 1970s saw many new developments in the field of drug metabolism. The Gordon Conference on Drug Metabolism began in 1970 and has been held every year since then (except 2020, due to the Covid-19 virus pandemic), bringing together leading scientists from academia, government, and the pharmaceutical industry to a pleasant venue in New Hampshire every July. (I chaired this meeting in 1988). In 1976 Testa and Jenner published a popular textbook on drug metabolism, Drug Metabolism: Chemical and Biochemical Aspects [46], which to a large extent succeeded the 1959s edition of Williams' text Detoxication Mechanisms [47]. This book focused more on drugs, on types of metabolism that were documented, and was a standard text for a number of years.

Extensive studies by Nebert and his associates appeared, particularly on the genetics of inducibility of aryl hydrocarbon hydroxylase in mice. Much of this work was related to cancer [48] but there were also some applications with drugs. Zoxazolamine metabolism, as measured by paralysis time, was related to the loss of the Ah receptor [49]. High doses of acetaminophen caused cataracts in mice, and Ahnonresponsive mice were protected [50].

Further work from Gillette, Mitchell, and their associates showed extensions of the acetaminophen story to other drugs, e.g., the furan furosemide [51-53]. That is, there was metabolic activation (presumably by P450) followed by covalent binding. This paradigm (Fig. 3) would be applied to numerous drugs (and still is), e.g., diclofenac (Fig. 4) and troglitazone (Fig. 5). Although not discussed here, there was a counterpart to this generation of reactive intermediates of pro-carcinogens to products that could react with DNA and cause cancer, as exemplified by the work of James and Elizabeth Miller [58] and Bruce Ames [59]. Later the efforts to utilize covalent binding to protein as a leading indicator of toxicity, especially idiosyncratic toxicity, would be emphasized in the pharmaceutical industry [60], although there is an appreciation that more is involved (vide infra).

\section{The age of P450s opens}

As already mentioned, $\mathrm{P} 450$ had been discovered in the early 1960s. By the late 1960s the question arose as to whether there was a single form of P450, two, or perhaps even more. Several lines of evidence suggested that there were at least two, on the basis of preferential induction of different catalytic activities by individual chemicals and by

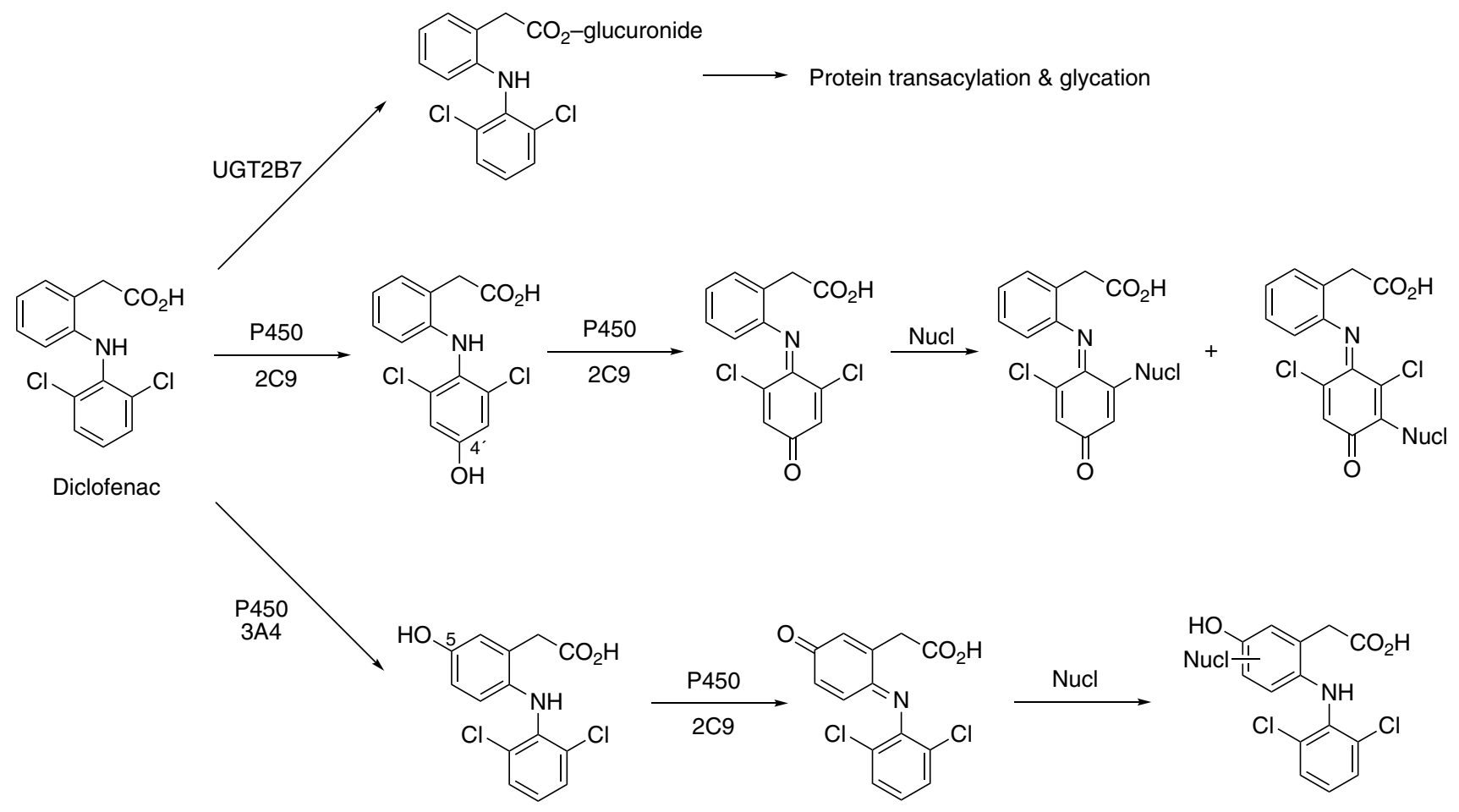

Fig. 4 Bioactivation of diclofenac. Nucl: nucleophile 


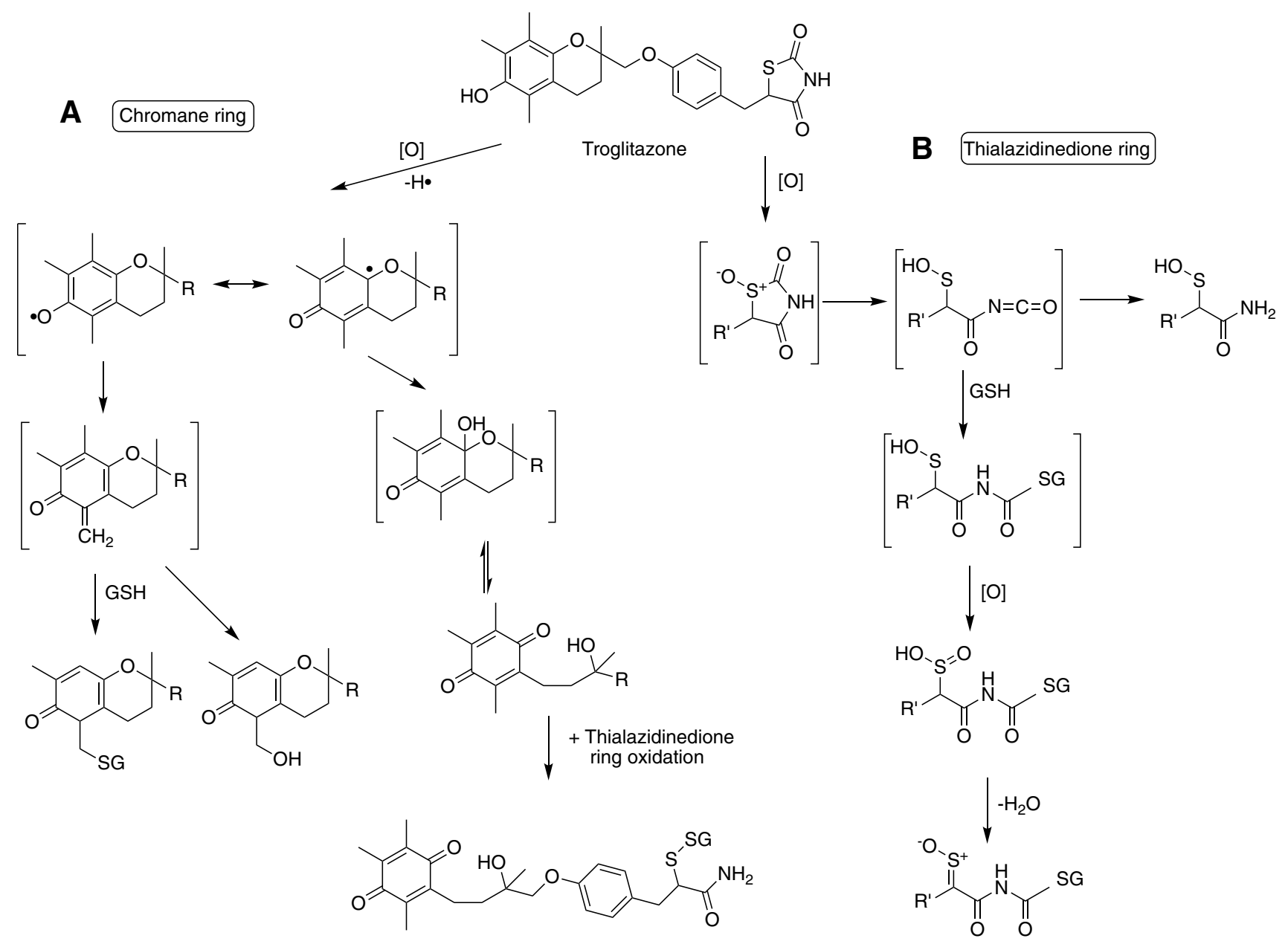

Fig. 5 Bioactivation of troglitazone [54-57]. a Activation of the chromane ring; b activation of the thialazidineone ring

the appearance of slightly altered but reproducible spectral differences [61, 62].

In 1968, the first Microsomes and Drug Oxidations conference was held in Bethesda, Maryland, USA [63]. Some of the major topics that the speakers discussed were whether P450 was synthesized in the rough or smooth endoplasmic reticulum, whether there were one or two P450s (some questioned whether changes in phospholipids might be responsible for the altered activities), the role of cytochrome $b_{5}$ (Estabrook, Mannering), the purification of P450 from rabbit liver (Coon, Sato), the chemical mechanism(s) of catalysis (Ullrich, McMahon, Udenfriend, Daly, Witkop, Jerina), and the biological basis of P450 induction. Some of these may seem to be unusual or esoteric topics today, but that was 53 years ago. Regarding induction, one question was whether new enzyme synthesis actually occurs - one must remember that many of the techniques we take for granted today did not exist then. This meeting is still held biennially (https://mdo.ki.se).
In $1968 \mathrm{Lu}$ and Coon [64] solubilized liver microsomes, separated the P450, NADPH-P450 reductase, and lipid components, and mixed these together to reconstitute catalytic activity ( $\omega$-hydroxylation of lauric acid). Work with this system was soon extended to drugs [65]. The purification of multiple forms of liver P450 [66] would answer the question of multiplicity.

Subsequently a number of individual P450s were purified from rabbit and rat liver [66-70] and their activities towards a number of drugs were characterized [71, 72]. These biochemical studies facilitated the understanding of many phenomena of in vivo investigations.

However, the work with rats and rabbits showed some interesting differences and several scientists realized that the human P450s would need to be characterized. At that time (late 1970s) access to useful human liver samples was problematic, but several investigators were working on the biochemistry [73-76]. While these early efforts did yield some purified proteins that can now be characterized based 
on further experience, there was only limited insight into their catalytic properties at the time. Important in vivo studies by Smith et al. [77-79] showed that the metabolism of a particular drug could be dominated by a single (putative) P450 enzyme. Accordingly, it should be possible to purify that enzyme from human tissue by monitoring catalytic activity. This is a technically challenging and very laborious approach, but it was used in our laboratory [80] to purify the enzymes now known as P450s 1A2 [81], 2C8 and 2C9 [82], 2D6 [81], and 3A4 [83].

In the next few years, the cDNAs were cloned and ultimately heterologous expression systems were developed to produce the enzymes [84-86]. With purified and recombinant enzymes it was possible to characterize individual P450s in terms of their substrate selectivity towards drugs [87], steroids [88], and chemical carcinogens [89], including situations where metabolism was related to toxicity [36, 90, 91].

In 1976, an international series of biennial meetings on the cytochrome $\mathrm{P} 450$ enzymes was established as a means of facilitating contact of scientists in this area working in Eastern Bloc and western countries but has developed into a timely international biennial series with meetings rotating among Europe, Asia, North America, and Australia. The first meeting was in (Primosten) Yugoslavia, in what is now Croatia. Issues addressed at these research meetings (International Conferences on Cytochrome P450, https:// www.p450meetings.com) include biochemistry, biophysics, gene regulation, and pharmaceutical and biotechnology applications.

\section{Animal models and human comparisons}

The ability to study individual human P450 reactions in vitro addressed a number of important comparisons with animals, which had been extensively relied on for pharmacokinetic data, as well as drug safety studies. Animal models are still utilized extensively in drug safety studies, particularly for hazard identification. However, risk assessment (the other key element in toxicology) utilizes principles gained through the study of human biochemistry.

One difference between humans and many animal models is $\mathrm{P} 450$ induction. For instance, peroxisome proliferation is much more robust in rodents than humans [92]. Differences in the pregnane $\mathrm{X}$ receptor (PXR) change ligand selectivity in the induction of P450 3A family members [93].

There are also qualitative differences in metabolism. In cynomolgus monkeys, P450 1A2 is not expressed and these are not good models for heterocyclic amines [94]. Human P450 2D6 has some important differences with the animal P450 2D Family P450s [95, 96]. One of the FDA issues is the relevance of "human specific metabolites", i.e., those present at levels $\geq 25 \%$ in humans that are not found or only found at low levels in experimental animals used for safety testing [97-99].

Rodents are notorious for sex differences, e.g., rat P450s $2 \mathrm{C} 11$ and 2C12 [100-102]. However, any sex differences in human P450 expression are minor [103]. This is an important point in considering the relevance of major sex differences in pre-clinical drug toxicity or carcinogenesis and their relevance to humans.

Not surprisingly, the differences between the P450s in humans and animals may generate drug toxicities that are seen in animals but not man-and also the opposite (e.g., thalidomide, vide supra). For instance, rat P450 2C11 was implicated in the metabolism of a drug candidate that released cyanide and caused brain problems only in male rats, which turned out to be irrelevant to the human situation [104]. Rabbit lung P450 4B1 activates the lung toxin 4-ipomenol. This toxic natural product was tested in humans as a lung cancer drug but was found to produce liver toxicity following bioactivation by P450s 1A2 and 3A4 [105], which are not expressed well in human lung. Human P450 1A2 is an order of magnitude more active than rat P450 1A2 in the bioactivation of several heterocyclic amines [106].

Another species difference is polymorphisms and other genetic variations. As already alluded to, polymorphisms were well known in rodents, especially mice, at least at the level of gene regulation, if not in coding regions [48]. Human P450 polymorphisms in what is now known as CYP2D6 were identified in the 1970s [77-79] and in the 1980s in P450 2C19 [107, 108]. (Note: by definition a polymorphism is present at $\geq 1 \%$ incidence in a population, and the term "variant" includes not only polymorphisms but all rare changes, and the term "single nucleotide variant" (SNV) is probably more generally appropriate, i.e., $\geq 160$ CYP2D6 SNVs are known (https://www.pharmvar.org/gene/CYP2D 6).) Today we realize that SNVs are seen in all human P450s (https://www.pharmvar.org/gene/CYP2D6). However the majority of SNVs do not affect catalytic activity (this is true for most genes). Many of the human SNVs have not been characterized in this regard. Moreover, coding-region SNVs may have different effects with different substrates and inhibitors, not surprisingly (e.g., P450 2C9 [109] and P450 3A4 [110]). Although animal models may provide interesting SNV and polymorphism models, the molecular basis is almost always different in humans.

\section{Advances in analytical chemistry}

The development of analytical chemistry has been crucial in studies of drug metabolism and toxicity, in that toxicokinetics requires measurements of concentrations and characterization of mechanisms usually requires 
identification of structures. One can appreciate the work that Williams and other early pioneers did with the very limited methods available. When did these methods develop?

The use of radioisotopes in metabolism studies began in the late 1940s. These methods, although now eclipsed by some others, proved to be invaluable in mass balance studies and in the measurement of covalent binding. They still provide the most accurate quantitation, especially when not all products or adducts have been characterized.

NMR spectroscopy really began in physics in the 1940s and was then applied in organic chemistry in the 1950s [111]. It has continued to develop in terms of both resolution and sensitivity. When I was a graduate student in the early 1970s, $60 \mathrm{MHz}$ was routine and $100 \mathrm{MHz}$ was reserved for difficult jobs. Today, with superconducting magnets, we routinely operate at $600 \mathrm{MHz}$, with twodimensional methods, and acquiring spectra with sub- $\mu \mathrm{g}$ samples is not an issue if samples are very pure [112].

Gas chromatography (GC) is also an invention of the 1950s [113], which developed in the the 1960s and was linked to mass spectrometry then [114]. At first, large-bore $(0.5 \mathrm{~cm}$ diameter) chromatography columns were packed by hand (I learned to do this as an undergraduate student). By the late 1970s these were displaced by with glass capillary columns, which provided much higher resolving power.

High performance liquid chromatography (HPLC) developed in the 1970s and by 1980 had become the method of choice in general. The use of reversed-phase packings is generally very convenient in terms of speed and resolution, aqueous samples can be loaded directly, and separation development is rather routine. Ultra-performance liquid chromatography (UPLC), with narrower bores and smaller particle sizes, developed in the mid2000s era.

It was not until the late 1980s that HPLC could be coupled directly with mass spectrometry, due to the development of electrospray ionization [115]. Mass spectrometry was already important, but most analysis had to be done off-line from HPLC, if GC-mass spectrometry was not used. LC-mass spectrometry has greatly facilitated the analysis of large molecules, in that formerly glucuronides and sulfates had to be hydrolyzed for analysis. High resolution mass spectrometry (HRMS) had long been possible with magnetic sector equipment, with its ability to determine elemental composition, but it has been greatly facilitated with the newer technology, e.g., Orbitrap and Q-Tof instruments. Further, ion trap methods have facilitated analysis of cleavage of molecules and identification of metabolites. Developments in imaging mass spectrometry since the mid-1990s have begun to facilitate drug distribution studies [116].

\section{SNVs, polymorphisms, and toxicity}

SNVs may influence drug toxicity in several ways. One of the most common is to accentuate the pharmacological effect due to lack of clearance. This is, for instance, how the CYP2D6 polymorphism was discovered, in that Robert Smith (personally) experienced a strong hypotensive effect of debrisoquine [77]. Other effects attributed to P450 2D6 deficiency are perhexiline neuropathy [117], phenformininduced lactic acidosis [118], and captopril-induced agranulocytosis [119]. Individuals deficient in P450 1A2 are unable to metabolize caffeine and theophylline well and therefore sensitive [120].

Conversely, some drugs are activated by $\mathrm{P} 450$ s, and there are SNVs that involve higher activity than wild type enzyme, e.g., CYP2D6*53 [121, 122]. In this regard, there are also gene duplication SNVs that lead to overproduction of a P450, e.g., P450 2D6 [123]. P450 2D6 converts codeine to morphine. In one unfortunate case a mother was an "ultrafast" P450 2D6 metabolizer and her nursing child died of morphine toxicity [124].

SNVs can raise problems with drug toxicity, and the FDA asks for evidence that any sensitive populations will not be at risk with a new chemical entity (drug candidate). Because of all of these issues, pharmaceutical companies prefer to develop drugs in which a single P450- or other enzyme - does not dominate the metabolism, particularly a highly polymorphic one such as P450 2D6 or 2C19 [125]. These considerations may also have racial implications and implications for particular markets, e.g. the incidence of P450 2C19 poor metabolizers is 15-20\% in East Asian countries [126]. Domination of the metabolism by a single P450 is an issue not only with regard to SNVs and polymorphisms but also with inducers and inhibitors regarding drug-drug interactions [127]. Other issues regarding toxicity due to a dominance of metabolism by a single P450 are low bioavailability and extensive first-pass clearance [127].

\section{Ethanol}

Historically the metabolism of ethanol has been attributed to alcohol and aldehyde dehydrogenases $[128,129]$. However, since the 1960s there have been evidence for a microsomal ethanol oxidation system that uses NADPH and produces acetaldehyde [130, 131]. Skepticism about a role for P450 existed, given the nature of ethanol as a small, polar molecule. Ultimately, the P450-catalyzed oxidation of ethanol was demonstrated to be done mainly by $\mathrm{P} 450$ 2E1 [132-134], and the acetaldehyde is also converted to 
acetic acid by P450 2E1 [135-137]. The contribution of the P450 pathway relative to alcohol and aldehyde dehydrogenases for ethanol oxidation can vary, tending to be more important at high concentrations [138].

There are at least four reasons for considering P450 2E1 in the context of drug toxicity. (1) Acetaldehyde is toxic itself and also generates DNA adducts, which may be involved in ethanol-linked cancers [139]. (2) Ethanol induces P450 2E1, and P450 2E1 acts on several drugs [140]. In particular, several low molecular weight anesthetics are substrates and low P450 2E1 could render an individual at risk. (3) P450 2E1 activates some drugs to reactive species, perhaps the most notable being acetaminophen, which has already been presented above. This may be a potential issue with acetaminophen toxicity (vide supra) in alcoholics. (4) Ethanol is also a competitive inhibitor of P450 2E1, in the short term, and can block the metabolism of drug substrates [140].

For a number of drugs (e.g., sedatives), ethanol is contraindicated but most of these situations are due to pharmacodynamic considerations, not pharmacokinetic.

\section{Toxicophores}

As the literature on P450 reactions, covalent binding, and drug toxicity grew, it became possible to develop lists of entities that could be activated to reactive forms by P450s, as well as other enzymes [141]. A current list, which is not intended to be comprehensive, is shown in Fig. 6. Some of the transformations are discussed elsewhere in this review, and others are presented in detail elsewhere [57, 142-147].

The presence of any these moieties in a prospective drug candidate should be a warning to a medicinal chemist that there is a possibility of bioactivation, which could take the form of mechanism-based inactivation, generation of electrophiles that bind proteins, and mutagenesis/ carcinogenicity (Fig. 1). Alternate structures should be considered, assuming that pharmacological efficacy is not lost. However, it should also be emphasized that the presence of one of these structures in a drug does not mean that bioactivation or toxicity will occur. For example, there are safe thiophene drugs on the market (Fig. 7). Derivatives of aniline are suspect (Fig. 8) and have been associated with a number of problems (e.g., acetaminophen, phenacetin) but the best-selling hypercholesterolemic drug atorvastatin (Lipitor ${ }^{\circledR}$ ) has a long history of safety (Fig. 7). Many good drugs contain carboxylic acids (which can have toxicity issues related to glucuronidation, Fig. 4). The point can also be made that even a simple phenyl ring is only one step away from a reactive product (i.e., epoxide). Nevertheless, the presence of one of the entities in Fig. 6 should trigger caution as one moves a compound on. If there is a choice among candidates, then the one devoid of these moieties would be preferred in the absence of other factors.<smiles>CNNCCOC(=O)OC(C)=O</smiles><smiles>O=C(O)CCc1ccccc1</smiles>

Arylacetic acids \& arylpropionic acids<smiles>c1ccsc1</smiles><smiles>c1ccoc1</smiles>

Thiophenes, furans, \& pyrroles<smiles>c1cc[nH]c1</smiles><smiles>CC(=O)Nc1ccccc1</smiles>

Anilines \& acetanilides<smiles>N=C1C=CC(=O)C=C1</smiles>

Quinones \& quinoneimines<smiles>CCCCCCCCCC(=O)O</smiles>

Medium chain length fatty acids<smiles>[X]CCC</smiles>

Alkyl hydrocarbons and halogenated aromatics

$(\mathrm{X}: \mathrm{I}>\mathrm{Br}>\mathrm{Cl}>\mathrm{F}$ )

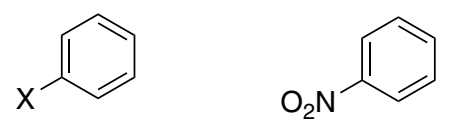

Nitroaromatics<smiles>CC1SC(=O)NC1=O</smiles>

Thiols, thiono compounds, thiazolidinediones

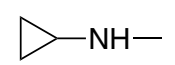

Cyclopropylamines
Moieties that form $\alpha, \beta$-unsaturated enol-like strucctures (Michael acceptors)<smiles>CC(C)=CC=CC(C)=CCCI</smiles>

Fig. 6 Toxicophores. Some moieties in drug candidates that require consideration regarding potential bioactivation [141-144] 

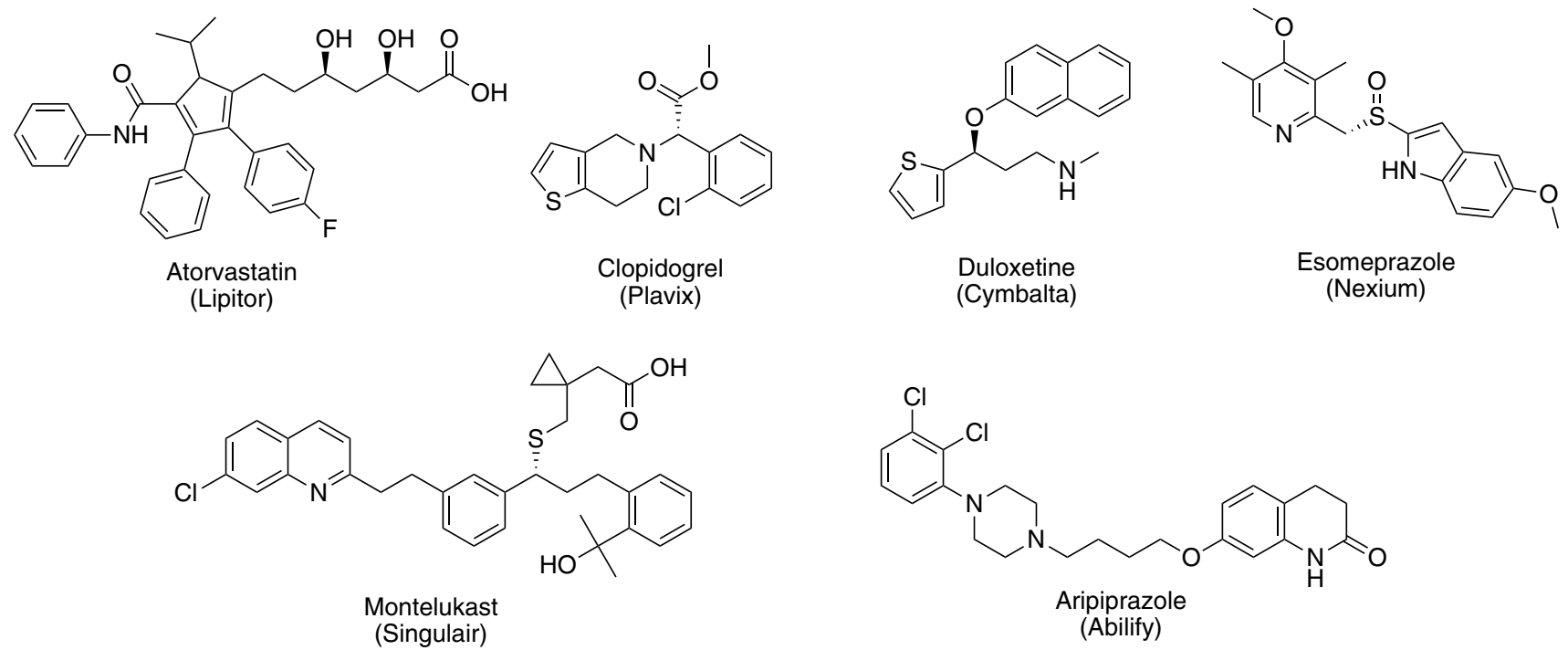

Fig. 7 Some molecules containing potential toxicophores that became successful drugs

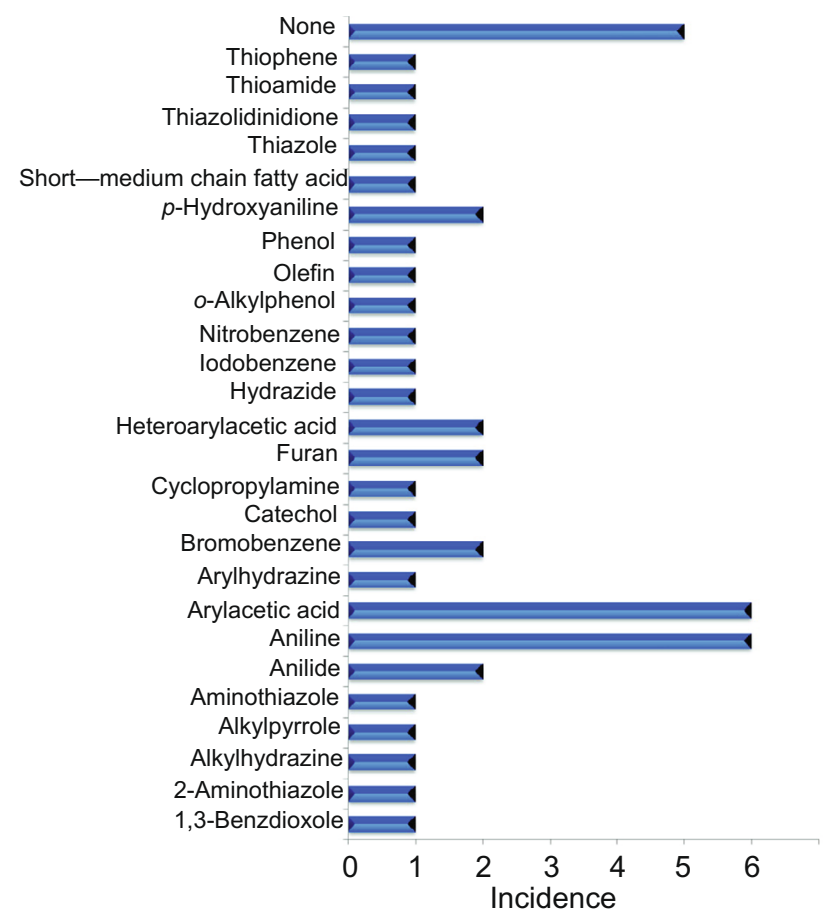

Fig. 8 Frequency of structural alerts in drugs associated with black box warnings [147]. Reprinted with permission from American Chemical Society. Antonia F. Stepan, Daniel P. Walker, Jonathan Bauman, David A. Price, Thomas A. Baillie, Amit S. Kalgutkar, and Michael D. Aleo, Chemical Research in Toxicology 24, 1345-1410, 2011

\section{Idiosyncratic toxicity}

Idiosyncratic means "individualized" here, and drugs in this category can be particularly problematic. The incidence of toxicity (often liver damage) is low, generally on the order of $1 / 10^{3}$ or even $1 / 10^{4}$. Even a large clinical trial might involve 30,000 individuals, so such problems may well be missed. Animal models have not been particularly useful in identifying idiosyncratic reactions, in that (1) similar numbers of animals would be required and (2) even if an idiosyncratic reaction is seen in animals the mechanism might differ from that in humans.

Bioactivation can be involved (Tables 1, 3). An interesting example is tienilic acid, a thiophene that is oxidized to either an $S$-oxide or an epoxide by P450 2 C9 [148, 149] (Fig. 9). Radioactivity from tienilic acid was bound almost exclusively to P450 2C9 in liver microsomes [148] (Fig. 10). Some of the patients administered tienilic acid also developed antibodies that recognized either free or tienilic acidconjugated P450 2C9 [148]. These events raise the hypothesis that bioactivation of tienilic acid, covalent binding, and formation of autoantibodies is a paradigm for the idiosyncratic liver damage [150]. It may be, but the presence of these antibodies has never been causally linked to hepatoxicity, and efforts to develop animal models have not been successful [151, 152]. These anti-P450 2C9 antibodies are also related to phenytoin exposure [153].

A similar situation was seen with dihydralazine and P450 1A2, i.e. bioactivation by P450 1A2, covalent binding to $\mathrm{P} 4501 \mathrm{~A} 2$, plus circulating antibodies that recognize P450 1A2 [154, 155] (Fig. 11). Again, a causal relationship between autoantibodies and liver toxicity is yet to be established. 
Table 3 Examples of links of bioactivation to idiosyncratic drug reactions [146]

\begin{tabular}{lll}
\hline Drugs withdrawn (United States) & $\begin{array}{l}\text { Temporarily withdrawn or } \\
\text { withdrawn in other countries }\end{array}$ & Marketed drugs \\
\hline
\end{tabular}

withdrawn in other countries

\begin{tabular}{ll}
\hline Aclofenac (anti-inflammatory) & Aminopyrine (analgesic) \\
Hepatitis, rash & Agranulocytosis \\
Alpidem (anxiolytic) & Nefazodone (antidepressant) \\
Hepatitis (fatal) & Hepatitis (>200 deaths) \\
Amodiaquine (antimalarial) & Trovan (antibacterial) \\
Hepatitis, agranulocytosis & Hepatitis \\
Amineptine (antidepressant) & Zileuton (antiasthma) \\
Hepatitis, cutaneous ADRs & Hepatitis
\end{tabular}

Benoxaprofen (anti-inflammatory)

Hepatitis, cutaneous ADRs

Bromfenac (anti-inflammatory)

Hepatitis (fatal)

Carbutamide (antidiabetic)

Bone marrow toxicity

Ibufenac (anti-inflammatory)

Hepatitis (fatal)

Iproniazid (antidepressant)

Hepatitis (fatal)

Metiamide (antiulcer)

Bone marrow toxicity

Nomifensine (antidepressant)

Hepatitis (fatal), anemia

Practolol (antiarrhythmic)

Severe cutaneous ADRs

Remoxipride (antipsychotic)

Aplastic anemia

Sudoxicam (anti-inflammatory)

Hepatitis (fatal)

Tienilic Acid (diuretic)

Hepatitis (fatal)

Tolrestat (antidiabetic)

Hepatitis (fatal)

Troglitazone (antidiabetic)

Hepatitis (fatal)

Zomepirac (anti-inflammatory)

Hepatitis, cutaneous ADRs
Abacavir (antiretroviral)

Cutaneous ADRs

Acetaminophen (analgesic)

Hepatitis (fatal)

Captopril (antihypertensive)

Cutaneous ADRs, agranulocytosis

Carbamazepine (anticonvulsant)

Hepatitis, agranulocytosis

Clozapine (antipsychotic)

Agranulocytosis

Cyclophosphamide (anticancer) Agranulocytosis, cutaneous ADRs

Dapsone (antibacterial)

Agranulocytosis, cutaneous ADRs, aplastic anemia

Diclofenac (anti-inflammatory)

Hepatitis

Felbamate (anticonvulsant)

Hepatitis (fatal), aplastic anemia (fatal), severe restriction in use

Furosemide (diuretic)

Agranulocytosis, cutaneous ADRs, aplastic anemia

Halothane (anesthetic)

Hepatitis

Imipramine (antidepressant)

Hepatitis

Indomethacin (anti-inflammatory)

Hepatitis

Isoniazid (antibacterial)

Hepatitis (can be fatal)

Phenytoin (anticonvulsant)

Agranulocytosis, cutaneous

ADRs

Procainamide (antiarrhythmic)

Hepatitis, agranulocytosis

Sulfamethoxazole (antibacterial)

Agranulocytosis, aplastic

anemia

Terbinafine (antifungal)

Hepatitis, cutaneous ADRs

Ticlopidine (antithrombotic)

Agranulocytosis, aplastic anemia

Tolcapone (anti-Parkinson's)

Hepatitis (fatal)

Trazodone (antidepressant)

Hepatitis

Trimethoprim (antibacterial)

Agranulocytosis, aplastic anemia, cutaneous ADRs

Thalidomide (immunomodulator)

Teratogenicity

Valproic acid (anticonvulsant)

Hepatitis (fatal), teratogenicity

$A D R$ Adverse drug reaction 
Fig. 9 Alternate mechanisms for the bioactivation of thiophenes [149]

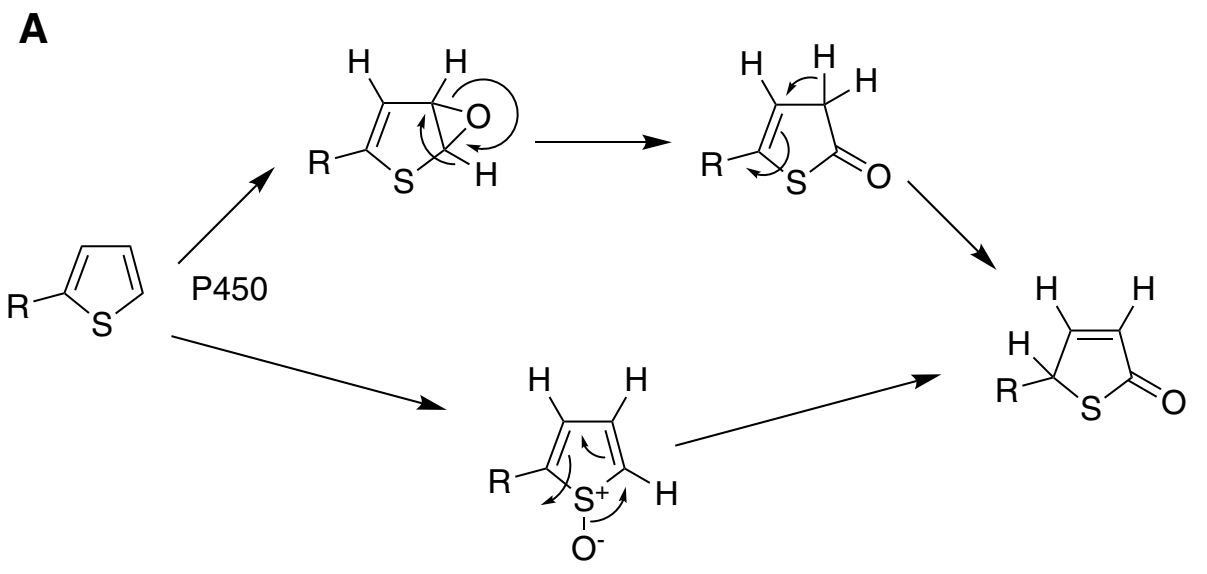

B
Some individuals also have autoantibodies to P450s 2D6 [156], although no drug association has never been established. With P450 2E1, the presence of autoantibodies is associated with exposure to halothane, an anesthetic substrate [157-159]. Interestingly, some people have anti-P450 $3 \mathrm{~A}$ autoantibodies after exposure to aromatic anticonvulsants (e.g., phenytoin) [160] but surprisingly the antibodies only recognize animal 3A family enzymes, not P450 3A4 [161].

Abacavir was shown to cause an immune hypersensitivity syndrome in individuals with the HLA-B*57:01 allele. In 2012 an X-ray crystal structure of the parent drug bound to HLA-B*57:01 protein showed the binding of abacavir (parent drug) to two amino acids unique to the variant and can explain the observed alteration in the preference for peptide binding that is associated with the hypersensitivity $[162,163]$. This is not related to bioactivation (the parent drug is the actor here) but does suggest that induced immune responses may have a more general role in liver toxicity. However, no similar scenario has been identified since then, and whether this is a more general paradigm for hepatoxicity remains to be established.

\section{Drug-drug interactions}

Some of these have already been presented. Drug-drug interactions cause a significant number of deaths each year. Better data is available for hospitalized patients, and in one report $7 \%$ of the patient deaths were attributed to drug-drug interactions [164].

Some of these are pharmacodynamic, but only pharmacokinetic issues will be discussed here. The general mechanism is for one drug to influence the metabolism of another (Table 1). This can be due to an increase or decrease in drug metabolism. In some of the literature one drug has 
<smiles>O=C(O)COc1ccc(C(=O)c2cccs2)c(Cl)c1Cl</smiles>

Tienilic acid

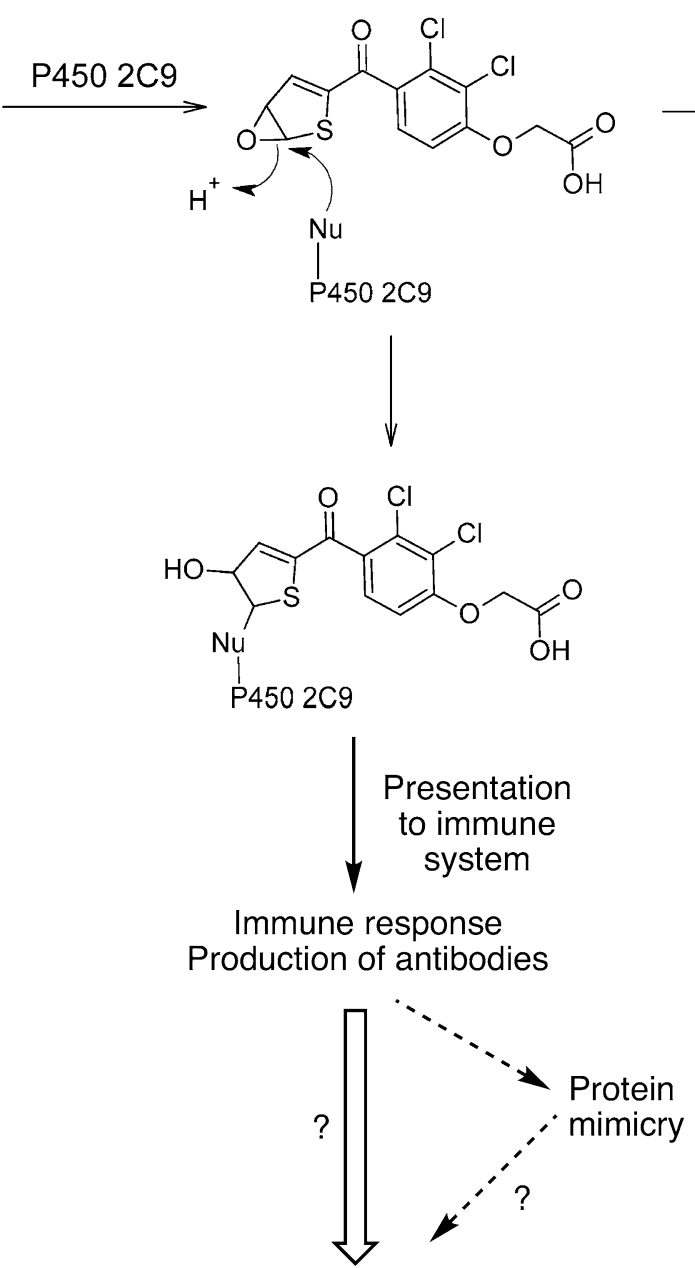

Cell lysis

Hepatotoxicity

Fig. 10 Bioactivation and generation of autoantibodies from tienilic acid [148]<smiles>CC(C)(C)CCc1ccc2c(NN)ccc(NN=O)c2c1</smiles>

Dihydralazine<smiles>O=C(O)COc1ccc(C(=O)c2ccc(O)s2)c(Cl)c1Cl</smiles><smiles>C=C=C</smiles><smiles>O=C(O)COc1ccc(C(=O)C2C=CC(=O)S2)c(Cl)c1Cl</smiles>

Anti-LKM antibodies (recognize unmodified P450 1A2) Cause/effect?

Liver toxicity

Fig. 11 Bioactivation and generation of autoantibodies from dihyralazine [154] 


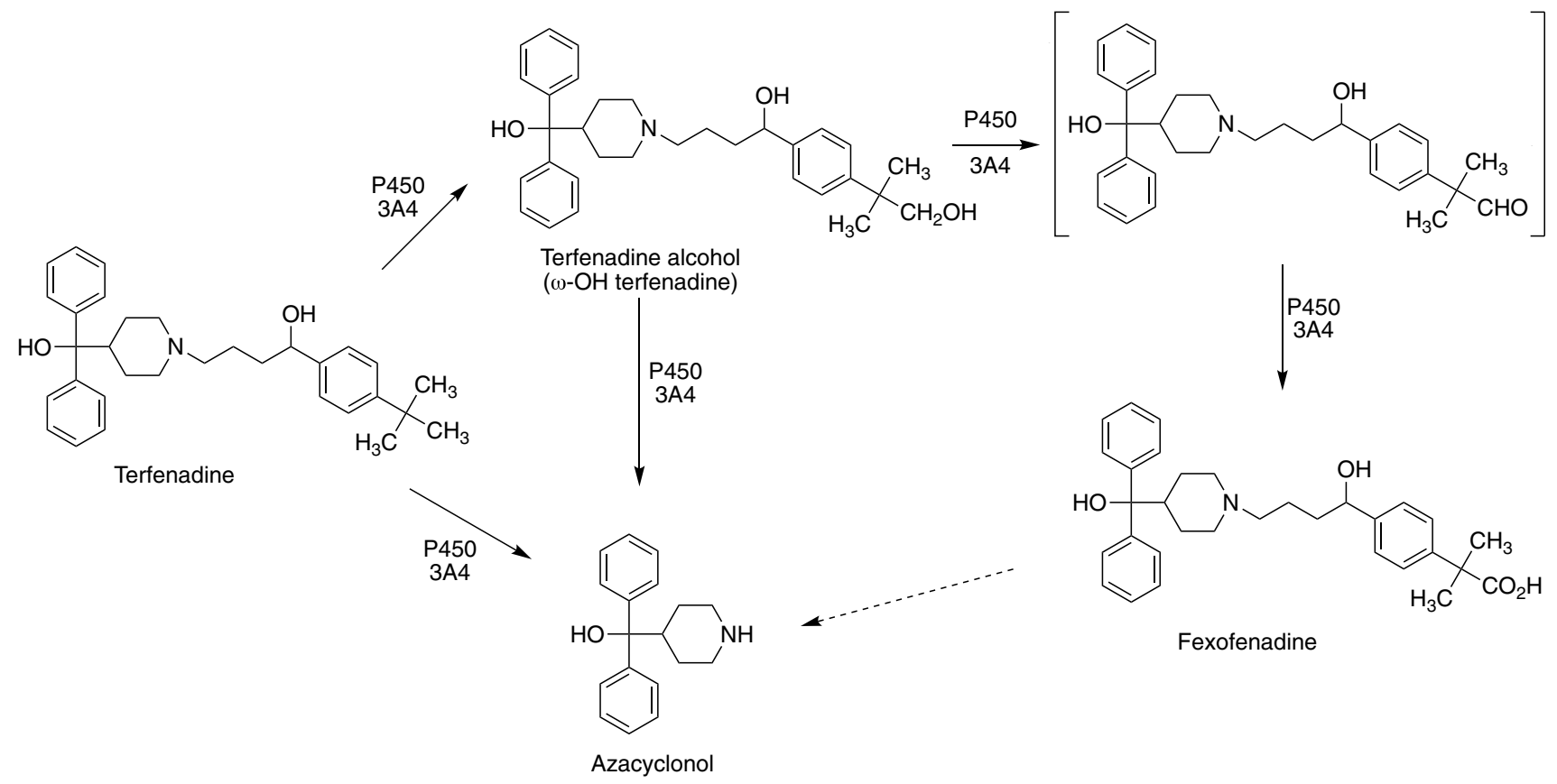

Fig. 12 Oxidation of terfenadine by P450 3A4 [90, 165]

been termed the "victim" and the other the "perpetrator", although this may not apply in some of the more complex situations. Most pharmacokinetic drug-drug interactions are due to either P450 induction or inhibition, mostly the latter (Table 1).

A classic example is that of terfenadine (Fig. 12) [90, 165], the first non-sedating antihistamine on the market. At least two million prescriptions for terfenadine (Seldane ${ }^{\circledR}$ ) were written, and for most individuals this drug provided relief from allergies without the side effect of drowsiness. However, some deaths were reported (estimated to be as many as 170). At the time, the manufacturer (Marion-Merrill-Dow) knew the pathways for metabolism (Fig. 12) but did not know which P450(s) was involved. On their request, our laboratory addressed the issue and implicated P450 3A4 [90], which was consistent with clinical reports of interactions with the inhibitors ketoconazole and erythromycin $[166,167]$. Inhibition of P450 3A4 (or just having very low levels otherwise) allows the parent drug to accumulate in plasma and to interact with the hERG ion channel. Subsequently the FDA required a contraindication warning and then later withdrew terfenadine from the market. The drug was replaced by the metabolite fexofenadine (Allegra ${ }^{\circledR}$ ) (Fig. 12), which had a successful history of its own and is still on the market as a generic drug [165]. This case shows how much the FDA - and the pharmaceutical industryhave changed since 1990, in terms of obtaining data on roles of P450 in the metabolism of new drug candidates, as a part of the drug development process.

\section{Drug-natural product interactions}

Although drug-drug interactions related to $\mathrm{P} 450$ activities are well-known, less is known about interactions with chemicals in two groups of natural products-food and herbal medicines. Both are complex mixtures.

Grapefruit juice was found, through a rather serendipitous clinical study [168], to inhibit the oxidation of the dihydropyridine calcium channel blocker and hypotensive agent felodipine, a P450 3A4 substrate [169]. This phenomenon is seen with many P450 3A4 substrates, particularly those in which much of the metabolism occurs in the small intestine [170]. The main entity in grapefruit juice responsible appears to be the furanocoumarin bergamottin (Fig. 13) $[171,172]$. Many drug labels for P450 3A4 substrates $(\geq 85)$ now carry contraindication warnings, and of these at least 43 drugs are considered serious [127]. Although the ingestion of grapefruit juice can increase the area-under-the-curve (AUC) several-fold [173-175], apparently no deaths have been attributed to this phenomenon.

An example of a drug-drug interaction, although not related to overt toxicity, involves $17 \alpha$-ethynylestradiol, the estrogenic component of most oral contraceptives. Induction of P450 3A4 by rifampicin and barbiturates leads to more rapid clearance and a lower AUC, thus to therapeutic ineffectiveness and unanticipated pregnancy [148, 176-178]. The same phenomenon has been reported with the herbal remedy St. John's wort [179], which contains the powerful PXR-dependent inducer hyperforin [180]. 


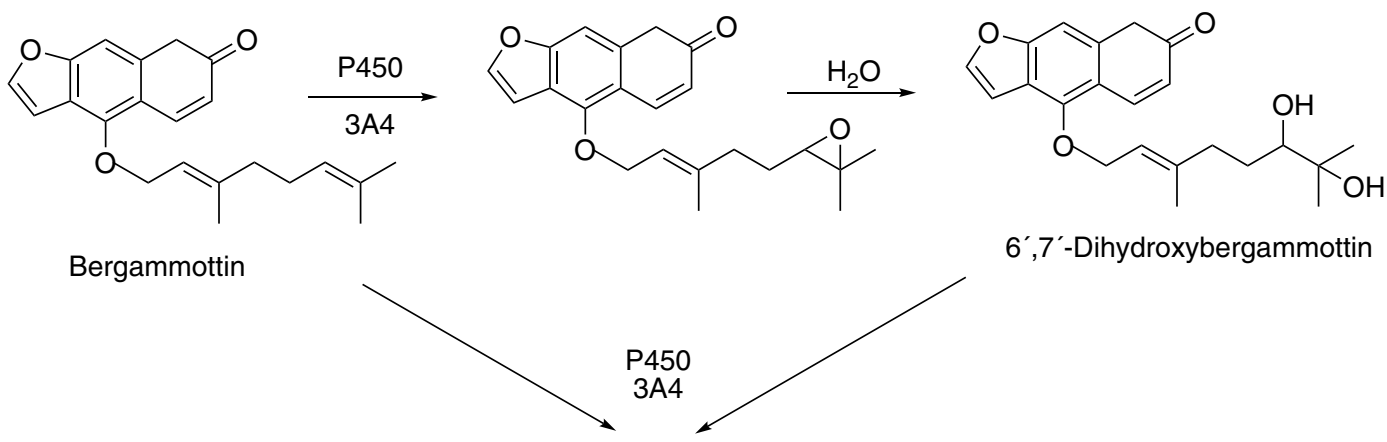<smiles>O=CC=C1C(=O)C=C2CC(=O)C=CC2=C1O</smiles>

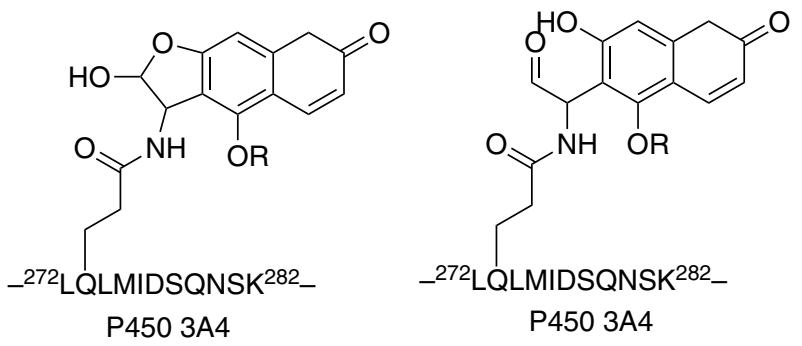

Fig. 13 Mechanism-based inactivation of P450 3A4 by bergamottin, a constituent of grapefruit juice [127, 171, 172]

\section{On-going issues}

Although much progress has been made, there are still things to learn. One deficiency is predicting the in vivo magnitude of $\mathrm{P} 450 \mathrm{SNV}$. For instance, even the $C Y P 2 D 6 * 3$ polymorphism, which results in loss of the entire enzyme due to aberrant mRNA splicing, has varying effects in vivo with different drugs [181], and the results cannot be explained simply by the contribution of other P450s. The prediction is even more complicated with coding region SNVs, e.g., those in P450 2C9 [109].

Drug-drug interactions can still be unpredictable. For instance, although ketoconazole is a strong inhibitor of P450 $3 \mathrm{~A} 4$, its effect on in vivo metabolism of different drugs can be rather variable [182]. The differences cannot be attributed only to the extent of first-pass metabolism in the small intestine.

Another issue is predicting time-dependent inhibition of P450s. This appears to be a particular issue with P450 3A4 [183, 184]. Many of the drugs that cause time-dependent inhibition do not have any of the common toxicophores (Figs. 6, 8) nor do they have the chemical characteristics of other known mechanism-based inhibitors, e.g., acetylenes. This is a problem in vitro as well as in vivo, in that a major effect on clearance can preclude candidates from development.

Although most of the interest in human drug metabolism centers around the five major hepatic P450s (1A2, 2C9, 2C19, 2D6, 3A4) [185], others can also contribute, including P450s 1A1, 2A6, 2B6, 2C8, 2E1, 2J2, 3A5, 3A7, and 4F2 [186]. A point of interest is that even P450s that are generally devoted to the metabolism of endogenous substrates (e.g., steroids, fatty acids) can also react with drugs and elicit effects [187]. An interesting example is P450 11A1 (Fig. 14). This enzyme catalyzes cholesterol side chain cleavage, the first committed step in steroid biosynthesis. However, it was implicated in the bioactivation of a drug candidate in the adrenal glands [188]. The Zhang et al. reference [188] contains a list of other drugs that interact with adrenal $\mathrm{P} 450 \mathrm{~s}$, including aminoglutethimide, metyrapone, etomidate, ketoconazole, and mitotane. Another interesting case is brain P450 46A1, which can act on and is also stimulated by drugs such as efavirenz [189, 190]. 


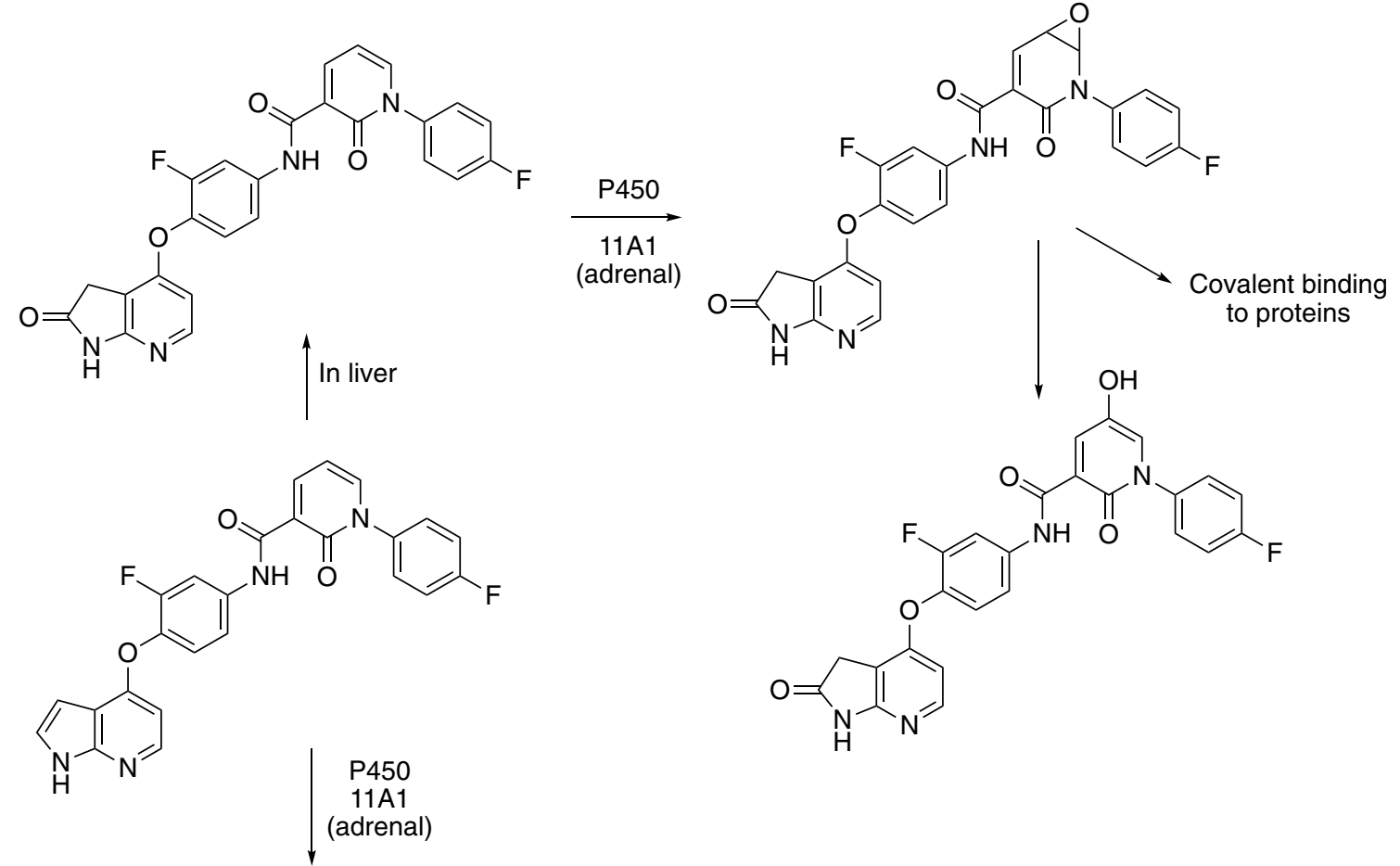

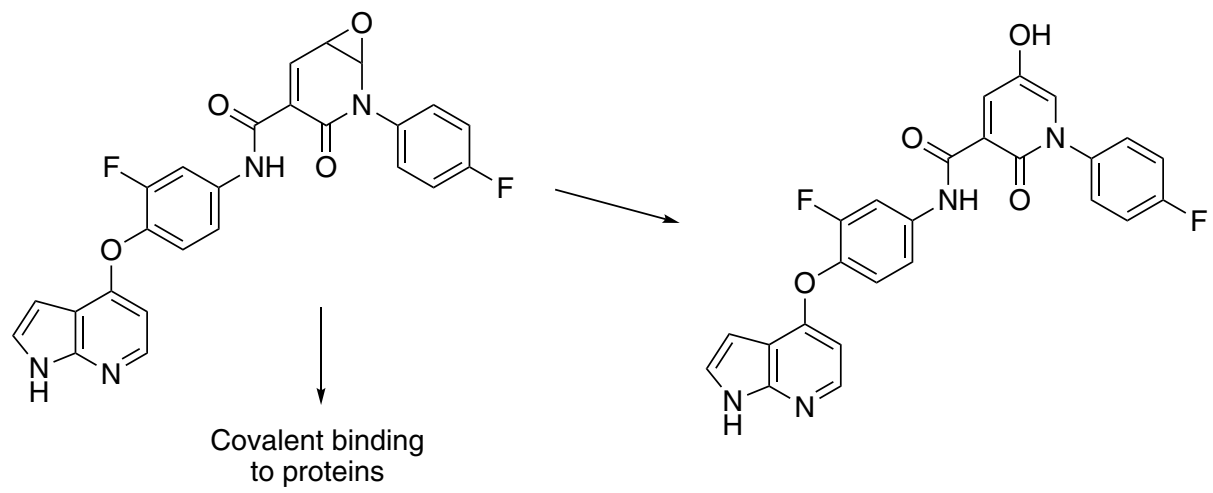

Fig. 14 Bioactivation of a drug candidate by adrenal mitochondrial P450 11A1 [188]

Another problem in drug toxicity is understanding the biology. Bioactivation can be assigned a causal role in drug toxicity through transgenic (knock-out) studies, at least in animals. In many cases, the covalent modification that results is generally regarded to be important (e.g., Figs. 1, 2, $3,4,5,9,10,11,12,13,14$, Tables 1,3 ) but the biology is less clear. In the 1970s and at least early 1980s, many in the field were of the opinion that there was a protein modified that was the "master switch" and could explain all toxicity. ATP-dependent calcium pumps were in vogue as candidates [191, 192]. However, with time, it has become clear that (1) many proteins (and other molecules) become modified [41] and (2) there are multiple pathways leading to toxicity in a cell [193]. There is also a continuum of effects of reactive electrophiles on cells ranging from evoking protective responses (e.g., anti-oxidant response element, KeapI/Nrf2) to apoptosis to necrosis [193].

Although recombinant P450 systems have been very useful in studying drug metabolism over the past 25-plus years, they cannot provide all of the answers regarding toxicity. There is a need for more complex systems that report cellular and tissue change. Humanized animal models (mice) are one solution, but in vitro systems are desirable, even if some of the requisite cellular complexity is lost. This remains a problem in the pharmaceutical industry, in that advancing toxic drug candidates is a very wasteful process.

A number of in vitro approaches have been discussed in recent literature [60, 194-200]. Different companies have varying approaches to predicting toxicity, although many of the main elements are similar. One approach taken in the 
TOX21 project, which is not driven by the pharmaceutical industry but does use some drugs, is the use of very highthroughput screens [201]. A major criticism of these can be made in that they have not incorporated metabolism capability, especially the use of P450s. One of the major issues in both hazard identification and risk assessment, the keystones of toxicology/safety evaluation, is deciding what is toxic: the parent compound or a metabolite. The point can be made that high-throughput toxicity screens devoid of metabolic capability resemble attempts at structure-activity relationship for mutagenesis before Ames introduced the use of liver post-mitochondrial supernatants ("S9") into the Salmonella typhimurium test system that now bears his name [59].

In closing, it should be pointed out that the focus of this review has been human drug toxicity. However, all of these issues need to be considered in the context of drugs used in veterinary practice as well [202-204].

Pulling all of this together in the context of dealing with numerous compounds and structural leads is difficult, but it is an integral part of pharmaceutical development. Some success has been achieved in in silico prediction of (chemical) sites of oxidation [205-207]. Because of the large database that has accumulated and the relative simplicity of mutagenesis, SAR has been useful in predicting genetic toxicology $[208,209]$ but not as well for toxicity $[201,210]$. However, toxicology in vivo or even a single tissue is complex and can involve many events [193], many of which probably remain to be described, posing an ongoing challenge to safety assessment in the pharmaceutical industry.

Acknowledgements This work was supported by United States National Institutes of Health grant R01 GM118122. Thanks are extended to $\mathrm{K}$. Trisler for assistance in preparation of the manuscript and to Y. Tateishi for the paradigm shown in Fig. 4. This review is dedicated to an old friend, Dr. Anthony Y. H. Lu, who shared my enthusiasm of $\mathrm{P} 450$ research for many years and introduced me to many applications in the pharmaceutical industry, and to the memory of our mutual mentor, Professor Minor J. Coon (1921-2018), who taught us both well.

\section{Compliance with ethical standards}

Conflict of interest The authors have no conflict of interest to disclose.

\section{References}

1. Walgren JL, Mitchell MD, Thompson DC (2005) Role of metabolism in drug-induced idiosyncratic hepatotoxicity. Crit Rev Toxicol 35:325-361

2. Borzelleca JF (2000) Profiles in toxicology-Paracelsus: herald of modern toxicology. Toxicol Sci 53:2-4

3. Wöhler F (1828) Über künstliche Bildung des Harnstoffs. Annal Physik Chemie 88:253-256

4. Bachmann C, Bickel MH (1985) History of drug metabolism: the first half of the 20th century. Drug Metab Rev 16:185-253. https ://doi.org/10.3109/03602538508991435
5. Guengerich FP (2018) Introduction and historical perspective. In: Guengerich FP (ed) Biotransformation, vol 10. Comprehensive toxicology (McQueen CA, Series ed), 3rd edn. Elsevier, Oxford, pp 1-7

6. Ambrose AM, Sherwin CP (1933) Detoxication mechanisms. Annu Rev Biochem 2:377-396. https://doi.org/10.1146/annur ev.bi.02.070133.002113

7. Handler P, Perlzweig WA (1945) Detoxication mechanisms. Annu Rev Biochem 14:617-642. https://doi.org/10.1146/annur ev.bi.14.070145.003153

8. Neuberger A, Smith RL (1983) Richard Tecwyn Williams: the man, his work, his impact. Drug Metab Rev 14:559-607. https ://doi.org/10.3109/03602538308991399

9. Williams RT (1947) Detoxication mechanisms, 1st edn. Wiley, New York

10. Brodie BB, Gillette JR, LaDu BN (1958) Enzymatic metabolism of drugs and other foreign compounds. Annu Rev Biochem 27:427-454

11. Remmer H (1959) The acceleration of evipan oxidation and the demethylation of methylaminopyrine by barbiturates. Naunyn Schmiedebergs Arch Exp Pathol Pharmakol 237:296-307

12. Remmer H (1957) The acceleration of evipan oxidation and the demethylation of methylaminopyrine by barbiturates. Naunyn Schmiedebergs Arch Exp Pathol Pharmakol 237:296-307

13. Conney AH, Miller EC, Miller JA (1956) The metabolism of methylated aminoazo dyes. V. Evidence for induction of enzyme synthesis in the rat by 3 -methylcholanthrene. Cancer Res 16:450-459

14. Garfinkel D (1958) Studies on pig liver microsomes. I. Enzymic and pigment composition of different microsomal fractions. Arch Biochem Biophys 77:493-509

15. Klingenberg M (1958) Pigments of rat liver microsomes. Arch Biochem Biophys 75:376-386

16. Omura T, Sato R (1962) A new cytochrome in liver microsomes. J Biol Chem 237:1375-1376

17. Omura T, Sato R (1964) The carbon monoxide-binding pigment of liver microsomes. I. Evidence for its hemoprotein nature. J Biol Chem 239:2370-2378

18. Omura T, Sato R (1964) The carbon monoxide-binding pigment of liver microsomes. II. Solubilization, purification, and properties. J Biol Chem 239:2379-2385

19. Cooper DY, Levine S, Narasimhulu S, Rosenthal O, Estabrook RW (1965) Photochemical action spectrum of the terminal oxidase of mixed function oxidase systems. Science 147:400-402

20. Speirs AL (1962) Thalidomide and congenital abnormalities. Lancet 1:303-305

21. Williams RT (1963) Teratogenic effects of thalidomide and related substances. Lancet 1:723-724. https://doi.org/10.1016/ s0140-6736(63)91486-7

22. Schumacher H, Smith RL, Williams RT (1965) The metabolism of thalidomide: The fate of thalidomide and some of its hydrolysis products in various species. Br J Pharmacol Chemother 25:338-351

23. Gordon GB, Spielberg SP, Blake DA, Balasubramanian V (1981) Thalidomide teratogenesis: evidence for a toxic arene oxide metabolite. Proc Natl Acad Sci USA 78:2545-2548

24. Yamazaki H, Suemizu H, Kazuki Y, Oofusa K, Kuribayashi S, Shimizu M, Ninomiya S, Horie T, Shibata N, Guengerich FP (2016) Assessment of protein binding of 5-hydroxythalidomide bioactivated in humanized mice with human P450 3A-chromosome or hepatocytes by two-dimensional electrophoresis/accelerator mass spectrometry. Chem Res Toxicol 29:1279-1281. https://doi.org/10.1021/acs.chemrestox.6b00210

25. Chowdhury G, Shibata N, Yamazaki H, Guengerich FP (2014) Human cytochrome P450 oxidation of 5-hydroxythalidomide 
and pomalidomide, an amino analogue of thalidomide. Chem Res Toxicol 27:147-156. https://doi.org/10.1021/tx4004215

26. Yamazaki H, Suemizu H, Shimizu M, Igaya S, Shibata N, Nakamura M, Chowdhury G, Guengerich FP (2012) In vivo formation of dihydroxylated and glutathione conjugate metabolites derived from thalidomide and 5-hydroxythalidomide in humanized TK-NOG mice. Chem Res Toxicol 25:274-276. https://doi. org/10.1021/tx300009j

27. Yamazaki H, Suemizu H, Igaya S, Shimizu M, Shibata N, Nakamura M, Chowdhury G, Guengerich FP (2011) In vivo formation of a glutathione conjugate derived from thalidomide in humanized uPA-NOG mice. Chem Res Toxicol 24:287-289. https://doi. org/10.1021/tx200005g

28. Chowdhury G, Murayama N, Okada Y, Uno Y, Shimizu M, Shibata N, Guengerich FP, Yamazaki H (2010) Human liver microsomal cytochrome P450 3A enzymes involved in thalidomide 5 -hydroxylation and formation of a glutathione conjugate. Chem Res Toxicol 23:1018-1024. https://doi.org/10.1021/tx900367p

29. Wani TH, Chakrabarty A, Shibata N, Yamazaki H, Guengerich FP, Chowdhury G (2017) The dihydroxy metabolite of the teratogen thalidomide causes oxidative DNA damage. Chem Res Toxicol 30:1622-1628. https://doi.org/10.1021/acs.chemrestox $.7 \mathrm{~b} 00127$

30. Ito T, Ando H, Suzuki T, Ogura T, Hotta K, Imamura Y, Yamaguchi Y, Handa H (2010) Identification of a primary target of thalidomide teratogenicity. Science 327:1345-1350

31. Larson AM, Polson J, Fontana RJ, Davern TJ, Lalani E, Hynan LS, Reisch JS, Schiodt FV, Ostapowicz G, Shakil AO, Lee WM (2005) Acetaminophen-induced acute liver failure: results of a United States multicenter, prospective study. Hepatology 42:1364-1372

32. Potter WZ, Davis DC, Mitchell JR, Jollow DJ, Gillette JR, Brodie BB (1973) Acetaminophen-induced hepatic necrosis. III. Cytochrome P-450-mediated covalent binding in vitro. J Exp Pharmacol Ther 187:203-210

33. Mitchell JR, Jollow DJ, Potter WZ, Gillette JR, Brodie BB (1973) Acetaminophen-induced hepatic necrosis. IV. Protective role of glutathione. J Exp Pharmacol Therap 187:211-217

34. Mitchell JR, Jollow DJ, Potter WZ, Davis DC, Gillette JR, Brodie BB (1973) Acetaminophen-induced hepatic necrosis. I. Role of drug metabolism. J Exp Pharmacol Ther 187:185-194

35. Jollow DJ, Mitchell JR, Potter WZ, Davis DC, Gillette JR, Brodie BB (1973) Acetaminophen-induced hepatic necrosis. II. Role of covalent binding in vivo. J Exp Pharmacol Ther 187:195-202

36. Patten CJ, Thomas PE, Guy RL, Lee M, Gonzalez FJ, Guengerich FP, Yang CS (1993) Cytochrome P450 enzymes involved in acetaminophen activation by rat and human liver microsomes and their kinetics. Chem Res Toxicol 6:511-518

37. Lee SST, Buters JTM, Pineau T, Fernandez-Salguero P, Gonzalez FJ (1996) Role of CYP2E1 in the hepatotoxicity of acetaminophen. J Biol Chem 271:12063-12067

38. Zaher H, Buters JT, Ward JM, Bruno MK, Lucas AM, Stern ST, Cohen SD, Gonzalez FJ (1998) Protection against acetaminophen toxicity in CYP1A2 and CYP2E1 double-null mice. Toxicol Appl Pharmacol 152:193-199

39. Dahlin DC, Nelson SD (1982) Synthesis, decomposition kinetics, and preliminary toxicological studies of pure $N$-acetyl-p-benzoquinone imine, a proposed toxic metabolite of acetaminophen. J Med Chem 25:885-886

40. Dahlin DC, Miwa GT, Lu AYH, Nelson SD (1984) N-Acetyl$p$-benzoquinone imine: a cytochrome P-450-mediated oxidation product of acetaminophen. Proc Natl Acad Sci USA 81:1327-1331

41. Qiu Y, Benet LZ, Burlingame AL (1998) Identification of the hepatic protein targets of reactive metabolites of acetaminophen in vivo in mice using two-dimensional gel electrophoresis and mass spectrometry. J Biol Chem 273:17940-17953

42. Streeter AJ, Bjorge SM, Axworthy DB, Nelson SD, Baillie TA (1984) The microsomal metabolism and site of covalent binding to protein of 3'-hydroxyacetanilide, a nonhepatotoxic positional isomer of acetaminophen. Drug Metab Dispos 12:565-576

43. Jaeschke H (2008) Innate immunity and acetaminophen-induced liver injury: why so many controversies? Hepatology 48:699701. https://doi.org/10.1002/hep.22556

44. Harrill AH, Watkins PB, Su S, Ross PK, Harbourt DE, Stylianou IM, Boorman GA, Russo MW, Sackler RS, Harris SC, Smith PC, Tennant R, Bogue M, Paigen K, Harris C, Contractor T, Wiltshire T, Rusyn I, Threadgill DW (2009) Mouse populationguided resequencing reveals that variants in CD44 contribute to acetaminophen-induced liver injury in humans. Genome Res 19:1507-1515

45. Court MH, Peter I, Hazarika S, Vasiadi M, Gresenblatt DJ, Lee WM, Acute Liver Failure Study Group (2014) Candidate gene polymorphisms in patients with acetaminophen-induced acute liver failure. Drug Metab Dispos 42:28-32. https://doi. org/10.1124/dmd.113.053546

46. Testa B, Jenner P (1976) Drug metabolism: chemical and biochemical aspects. Marcel Dekker, New York

47. Williams RT (1959) Detoxication mechanisms, 2nd edn. Wiley, New York

48. Nebert DW (1989) The $A h$ locus: genetic differences in toxicity, cancer, mutation, and birth defects. Crit Rev Toxicol 20:153-174

49. Robinson JR, Nebert DW (1974) Genetic expression of aryl hydrocarbon hydroxylase induction. Presence or absence of association with zoxazolamine, diphenylhydantoin, and hexobarbital metabolism. Mol Pharmacol 10:484-493

50. Shichi H, Gaasterland DE, Jensen NM, Nebert DW (1978) Ah locus: genetic differences in susceptibility to cataracts induced by acetaminophen. Science 200:539-541

51. Mitchell JR, Potter WZ, Hinson JA, Jollow DJ (1974) Hepatic necrosis caused by furosemide. Nature 251:508-511

52. Wirth PJ, Bettis CJ, Nelson WL (1976) Microsomal metabolism of furosemide evidence for the nature of the reactive intermediate involved in covalent binding. Mol Pharmacol 12:759-768

53. McMurtry RJ, Mitchell JR (1977) Renal and hepatic necrosis after metabolic activation of 2-substituted furans and thiophenes, including furosemide and cephaloridine. Toxicol Appl Pharmacol 42:285-300

54. Yamazaki H, Shibata A, Suzuki M, Nakajima M, Shimada N, Guengerich FP, Yokoi T (1999) Oxidation of troglitazone to a quinone-type metabolite catalyzed by cytochrome P-450 2C8 and P-450 3A4 in human liver microsomes. Drug Metab Dispos 27:1260-1266

55. Kassahun K, Pearson PG, Tang W, McIntosh I, Leung K, Elmore C, Dean D, Wang R, Doss G, Baillie TA (2001) Studies on the metabolism of troglitazone to reactive intermediates in vitro and in vivo. Evidence for novel biotransformation pathways involving quinone methide formation and thiazolidinedione ring scission. Chem Res Toxicol 14:62-70

56. Reddy VB, Karanam BV, Gruber WL, Wallace MA, Vincent SH, Franklin RB, Baillie TA (2005) Mechanistic studies on the metabolic scission of thiazolidinedione derivatives to acyclic thiols. Chem Res Toxicol 18:880-888

57. Isin EM, Guengerich FP (2007) Complex reactions catalyzed by cytochrome P450 enzymes. Biochim Biophys Acta 1770:314329. https://doi.org/10.1016/j.bbagen.2006.07.003

58. Miller JA (1970) Carcinogenesis by chemicals: an overview. G.H.A Clowes memorial lecture. Cancer Res 30:559-576

59. Ames BN, Durston WE, Yamasaki E, Lee FD (1973) Carcinogens are mutagens: a simple test system combining liver 
homogenates for activation and bacteria for detection. Proc Natl Acad Sci USA 70:2281-2285

60. Evans DC, Watt AP, Nicoll-Griffith DA, Baillie TA (2004) Drug-protein adducts: an industry perspective on minimizing the potential for drug bioactivation in drug discovery and development. Chem Res Toxicol 17:3-16

61. Hildebrandt A, Remmer H, Estabrook RW (1968) Cytochrome P-450 of liver microsomes: one pigment or many. Biochem Biophys Res Commun 30:607-612

62. Sladek NE, Mannering GJ (1969) Induction of drug metabolism. II. Qualitative differences in the microsomal $N$-demethylating systems stimulated by polycyclic hydrocarbons and by phenobarbital. Mol Pharmacol 5:186-199

63. Gillette JR, Conney AH, Cosmides GJ, Estabrook RW, Fouts JR, Mannering GJ (1969) Microsomes and drug oxidations. Academic Press, New York

64. Lu AYH, Coon MJ (1968) Role of hemoprotein P-450 in fatty acid w-hydroxylation in a soluble enzyme system from liver microsomes. J Biol Chem 243:1331-1332

65. Lu AYH, Strobel HW, Coon MJ (1969) Hydroxylation of benzphetamine and other drugs by a solubilized form of cytochrome P-450 from liver microsomes: lipid requirement for drug demethylation. Biochem Biophys Res Commun 36:545-551

66. Haugen DA, van der Hoeven TA, Coon MJ (1975) Purified liver microsomal cytochrome P-450: separation and characterization of multiple forms. J Biol Chem 250:3567-3570

67. Imai Y, Sato R (1974) A gel-electrophoretically homogeneous preparation of cytochrome P-450 from liver microsomes of phenobarbital-pretreated rabbits. Biochem Biophys Res Commun $60: 8-14$

68. Johnson EF, Muller-Eberhard U (1977) Purification of the major cytochrome P-450 of liver microsomes from rabbits treated with 2,3,7,8-tetrachlorodibenzo- $p$-dioxin (TCDD). Biochem Biophys Res Commun 76:652-659

69. Ryan D, Lu AYH, Kawalek J, West SB, Levin W (1975) Highly purified cytochrome P-448 and P-450 from rat liver microsomes. Biochem Biophys Res Commun 64:1134-1141

70. Guengerich FP (1978) Separation and purification of multiple forms of microsomal cytochrome P-450. Partial characterization of three apparently homogeneous cytochromes P-450 prepared from livers of phenobarbital- and 3-methylcholanthrene-treated rats. J Biol Chem 253:7931-7939

71. Guengerich FP (1977) Separation and purification of multiple forms of microsomal cytochrome P-450. Activities of different forms of cytochrome P-450 towards several compounds of environmental interest. J Biol Chem 252:3970-3979

72. Thomaszewski JE, Jerina DM, Levin W, Conney AH (1976) A highly senstivive radiometric assay for zoxazolamine hydroxylation by liver microsomal cytochrome $\mathrm{P}-450$ and $\mathrm{P}-448$ : properties of the membrane-bound and purified reconstituted system. Arch Biochem Biophys 176:788-798

73. Beaune P, Dansette P, Flinois JP, Columelli S, Mansuy D, Leroux J-P (1979) Partial purification of human liver cytochrome P-450. Biochem Biophys Res Commun 88:826-832

74. Kitada M, Kamataki T (1979) Partial purification and properties of cytochrome P450 from homogenates of human fetal livers. Biochem Pharmacol 28:793-797

75. Wang P, Mason PS, Guengerich FP (1980) Purification of human liver cytochrome P-450 and comparison to the enzyme isolated from rat liver. Arch Biochem Biophys 199:206-219

76. Wang PP, Beaune P, Kaminsky LS, Dannan GA, Kadlubar FF, Larrey D, Guengerich FP (1983) Purification and characterization of six cytochrome P-450 isozymes from human liver microsomes. Biochemistry 22:5375-5383
77. Mahgoub A, Idle JR, Dring LG, Lancaster R, Smith RL (1977) Polymorphic hydroxylation of debrisoquine in man. Lancet 2:584-586

78. Tucker GT, Silas JH, Iyun AO, Lennard MS, Smith AJ (1977) Polymorphic hydroxylation of debrisoquine. Lancet 2:718

79. Eichelbaum M, Spannbrucker N, Steincke B, Dengler HJ (1979) Defective $N$-oxidation of sparteine in man: a new pharmacogenetic defect. Eur J Clin Pharmacol 16:183-187

80. Mukhopadhyay R (2012) Human cytochrome P450s: the work of Frederick Peter Guengerich. J Biol Chem 287:15798-15800. https://doi.org/10.1074/jbc.O112.000003

81. Distlerath LM, Reilly PE, Martin MV, Davis GG, Wilkinson GR, Guengerich FP (1985) Purification and characterization of the human liver cytochromes P-450 involved in debrisoquine 4-hydroxylation and phenacetin $O$-deethylation, two prototypes for genetic polymorphism in oxidative drug metabolism. J Biol Chem 260:9057-9067

82. Shimada T, Misono KS, Guengerich FP (1986) Human liver microsomal cytochrome P-450 mephenytoin 4-hydroxylase, a prototype of genetic polymorphism in oxidative drug metabolism. Purification and characterization of two similar forms involved in the reaction. J Biol Chem 261:909-921

83. Guengerich FP, Martin MV, Beaune PH, Kremers P, Wolff T, Waxman DJ (1986) Characterization of rat and human liver microsomal cytochrome $\mathrm{P}-450$ forms involved in nifedipine oxidation, a prototype for genetic polymorphism in oxidative drug metabolism. J Biol Chem 261:5051-5060

84. Barnes HJ, Arlotto MP, Waterman MR (1991) Expression and enzymatic activity of recombinant cytochrome P450 $17 \alpha$-hydroxylase in Escherichia coli. Proc Natl Acad Sci USA 88:5597-5601

85. Li YC, Chiang JYL (1991) The expression of a catalytically active cholesterol $7 \alpha$-hydroxylase cytochrome P-450 in Escherichia coli. J Biol Chem 266:19186-19191

86. Larson JR, Coon MJ, Porter TD (1991) Purification and properties of a shortened form of cytochrome P-450 2E1: deletion of the $\mathrm{NH}_{2}$-terminal membrane-insertion signal peptide does not alter the catalytic activities. Proc Natl Acad Sci USA 88:9141-9145

87. Wang RW, Kari PH, Lu AY, Thomas PE, Guengerich FP, Vyas KP (1991) Biotransformation of lovastatin. IV. Identification of cytochrome $\mathrm{P} 4503 \mathrm{~A}$ proteins as the major enzymes responsible for the oxidative metabolism of lovastatin in rat and human liver microsomes. Arch Biochem Biophys 290:355-361

88. Waxman DJ, Attisano C, Guengerich FP, Lapenson DP (1988) Human liver microsomal steroid metabolism: identification of the major microsomal steroid hormone $6 \beta$-hydroxylase cytochrome P-450 enzyme. Arch Biochem Biophys 263:424-436

89. Shimada T, Iwasaki M, Martin MV, Guengerich FP (1989) Human liver microsomal cytochrome P-450 enzymes involved in the bioactivation of procarcinogens detected by umu gene response in Salmonella typhimurium TA 1535/pSK1002. Cancer Res 49:3218-3228

90. Yun CH, Okerholm RA, Guengerich FP (1993) Oxidation of the antihistaminic drug terfenadine in human liver microsomes. Role of cytochrome P-450 3A(4) in $N$-dealkylation and $C$-hydroxylation. Drug Metab Dispos 21:403-409

91. Garcia MPL, Dansette PM, Valadon P, Amar C, Beaune PH, Guengerich FP, Mansuy D (1993) Human-liver cytochromes P-450 expressed in yeast as tools for reactive-metabolite formation studies. Oxidative activation of tienilic acid by cytochromes P-450 2C9 and 2C10. Eur J Biochem 213:223-232

92. Palmer CNA, Hsu MH, Griffin KJ, Raucy JL, Johnson EF (1998) Peroxisome proliferator activated receptor- $a$ expression in human liver. Mol Pharmacol 53:14-22 
93. Kliewer SA (2015) Nuclear receptor PXR: discovery of a pharmaceutical anti-target. J Clin Invest 125:1388-1389. https://doi. org/10.1172/jci81244

94. Davis CD, Adamson RH, Snyderwine EG (1993) Studies on the mutagenic activation of heterocylic amines by cynomolgus monkey, rat and human microsomes show that cynomolgus monkeys have a low capacity to $N$-oxidize the quinoxaline-type heterocyclic amines. Cancer Lett 73:95-104

95. Hosseinpour F, Wikvall K (2000) Porcine microsomal vitamin $\mathrm{D}_{3}$ 25-hydroxylase (CYP2D25) - catalytic properties, tissue distribution, and comparison with human CYP2D6. J Biol Chem 275:34650-34655

96. Hiroi T, Chow T, Imaoka S, Funae Y (2002) Catalytic specificity of CYP2D isoforms in rat and human. Drug Metab Dispos 30:970-976

97. Baillie TA, Cayen MN, Fouda H, Gerson RJ, Green JD, Grossman SJ, Klunk LJ, LeBlanc B, Perkins DG, Shipley LA (2002) Drug metabolites in safety testing. Toxicol Appl Pharmacol 182:188-196

98. Smith DA, Obach RS (2005) Seeing through the mist: abundance versus percentage. Commentary on metabolites in safety testing. Drug Metab Dispos 33:1409-1417

99. Guengerich FP (2009) Introduction: human metabolites in safety testing (MIST) issue. Chem Res Toxicol 22:237-238. https://doi. org/10.1021/tx900003k

100. Kamataki T, Maeda K, Yamazoe Y, Nagai T, Kato R (1982) Evidence for the involvement of multiple forms of cytochrome P-450 in the occurrence of sex-related differences of drug metabolism in the rat. Life Sci 31:2603-2610

101. Waxman DJ, Dannan GA, Guengerich FP (1985) Regulation of rat hepatic cytochrome P-450: age-dependent expression, hormonal imprinting, and xenobiotic inducibility of sex-specific isoenzymes. Biochemistry 24:4409-4417

102. Dannan GA, Guengerich FP, Waxman DJ (1986) Hormonal regulation of rat liver microsomal enzymes. Role of gonadal steroids in programming, maintenance, and suppression of $\Delta 4$-steroid $5 \alpha$-reductase, flavin-containing monooxygenase, and sex-specific cytochromes P-450. J Biol Chem 261:10728-10735

103. Yang X, Zhang B, Molony C, Chudin E, Hao K, Zhu J, Gaedigk A, Suver C, Zhong H, Leeder JS, Guengerich FP, Strom SC, Schuetz E, Rushmore TH, Ulrich RG, Slatter JG, Schadt EE, Kasarskis A, Lum PY (2010) Systematic genetic and genomic analysis of cytochrome P450 enzyme activities in human liver. Genome Res 20:1020-1036. https://doi.org/10.1101/gr.10334 1.109

104. Su H, Boulton DW, Barros A, Wang LF, Cao K, Bonacorsi SJ, Iyer RA, Humphreys WG, Christopher LJ (2012) Characterization of the in vitro and in vivo metabolism and disposition and cytochrome P450 inhibition/induction profile of saxagliptin in human. Drug Metab Dispos 40:1345-1356. https://doi. org/10.1124/dmd.112.045450

105. Czerwinski M, McLemore TL, Philpot RM, Nhamburo PT, Korzekwa K, Gelboin HV, Gonzalez FJ (1991) Metabolic activation of 4-ipomeanol by complementary DNA-expressed human cytochromes P-450: evidence for species-specific metabolism. Cancer Res 51:4636-4638

106. Turesky RJ, Constable A, Richoz J, Varga N, Markovic J, Martin MV, Guengerich FP (1998) Activation of heterocyclic aromatic amines by rat and human liver microsomes and by purified rat and human cytochrome P450 1A2. Chem Res Toxicol 11:925936. https://doi.org/10.1021/tx980022n

107. Küpfer A, Preisig R (1984) Pharmacogenetics of mephenytoin: a new drug hydroxylation polymorphism in man. Eur J Clin Pharmacol 26:753-759

108. Wedlund PJ, Aslanian WS, McAllister CB, Wilkinson GR, Branch RA (1984) Mephenytoin hydroxylation deficiency in
Caucasians: frequency of a new oxidative drug metabolism polymorphism. Clin Pharmacol Ther 36:773-780

109. Maekawa K, Harakawa N, Sugiyama E, Tohkin M, Kim SR, Kaniwa N, Katori N, Hasegawa R, Yasuda K, Kamide K, Miyata T, Saito Y, Sawada J (2009) Substrate-dependent functional alterations of seven CYP2C9 variants found in Japanese subjects. Drug Metab Dispos 37:1895-1903. https://doi. org/10.1124/dmd.109.027003

110. Akiyoshi T, Saito T, Murase S, Miyazaki M, Murayama N, Yamazaki H, Guengerich FP, Nakamura K, Yamamoto K, Ohtani H (2011) Comparison of the inhibitory profiles of itraconazole and cimetidine in cytochrome P450 3A4 genetic variants. Drug Metab Dispos 39:724-728. https://doi.org/10.1124/ dmd.110.036780

111. Roberts JD (1961) Nuclear magnetic resonance spectroscopy. J Chem Educ 38:581. https://doi.org/10.1021/ed038p581

112. Krauser JA, Voehler M, Tseng LH, Schefer AB, Godejohann M, Guengerich FP (2004) Testosterone $1 \beta$-hydroxylation by human cytochrome P450 3A4. Eur J Biochem 271:3962-3969. https://doi.org/10.1111/j.1432-1033.2004.04339.x

113. James AT, Martin AJ (1952) Gas-liquid partition chromatography; the separation and micro-estimation of volatile fatty acids from formic acid to dodecanoic acid. Biochem J 50:679-690. https://doi.org/10.1042/bj0500679

114. Watson JT, Biemann K (1965) Direct recording of high resolution mass spectra of gas chromatographic effluents. J Mass Spectrom 37:844-851. https://doi.org/10.1002/(SICI)10969888(199802)33:2<109::AID-JMS634>3.0.CO;2-E

115. Whitehouse CM, Dreyer RN, Yamashita M, Fenn JB (1985) Electrospray interface for liquid chromatographs and mass spectrometers. Anal Chem 57:675-679. https://doi. org/10.1021/ac00280a023

116. Caprioli RM, Farmer TB, Gile J (1997) Molecular imaging of biological samples: localization of peptides and proteins using MALDI-TOF MS. Anal Chem 69:4751-4760

117. Shah RR, Oates NS, Idle JR, Smith RL, Lockhart JDF (1982) Impaired oxidation of debrisoquine in patients with perhexiline neuropathy. Br Med J 284:295-299

118. Oates NS, Shah RR, Idle JR, Smith RL (1981) Phenformininduced lactic acidosis associated with impaired debrisoquine hydroxylation. Lancet 1:837-838

119. Oates NS, Shah RR, Drury PL, Idle JR, Smith RL (1982) Captopril-induced agranulocytosis associated with an impairment of debrisoquine hydroxylation. Br J Pharmacol 14:601P

120. Sohn JA, Kim HS, Oh J, Cho JY, Yu KS, Lee J, Shin SH, Lee JA, Choi CW, Kim EK, Kim BI, Park EA (2017) Prediction of serum theophylline concentrations and cytochrome P450 1A2 activity by analyzing urinary metabolites in preterm infants. Br J Clin Pharmacol 83:1279-1286. https://doi.org/10.1111/ bcp. 13211

121. Muroi Y, Saito T, Takahashi M, Sakuyama K, Niinuma Y, Ito M, Tsukada C, Ohta K, Endo Y, Oda A, Hirasawa N, Hiratsuka M (2014) Functional characterization of wild-type and 49 CYP2D6 allelic variants for $N$-desmethyltamoxifen 4-hydroxylation activity. Drug Metab Pharmacokinet 29:360-366. https://doi. org/10.2133/dmpk.DMPK-14-RG-014

122. Sakuyama K, Sasaki T, Ujiie S, Obata K, Mizugaki M, Ishikawa M, Hiratsuka M (2008) Functional characterization of 17 CYP2D6 allelic variants (CYP2D6.2, 10, 14A-B, 18, 27, 36, 39, 47-51, 53-55, and 57). Drug Metab Dispos 36:2460. https://doi. org/10.1124/dmd.108.023242

123. Johansson I, Lundqvist E, Bertilsson L, Dahl ML, Sjoqvist F, Ingelman-Sundberg M (1993) Inherited amplification of an active gene in the cytochrome $\mathrm{P} 450 \mathrm{CYP} 2 \mathrm{D}$ locus as a cause of ultrarapid metabolism of debrisoquine. Proc Natl Acad Sci USA 90:11825-11829 
124. Koren G, Cairns J, Chitayat D, Gaedigk A, Leeder SJ (2006) Pharmacogenetics of morphine poisoning in a breastfed neonate of a codeine-prescribed mother. Lancet 368:704. https:// doi.org/10.1016/S0140-6736(06)69255-6

125. Obach RS, Cox LM, Tremaine LM (2005) Sertraline is metabolized by multiple cytochrome $\mathrm{P} 450$ enzymes, monoamine oxidases, and glucuronyl transferases in human: an in vitro study. Drug Metab Dispos 33:262-270. https://doi.org/10.1124/ dmd.104.002428

126. Nakamura K, Goto F, Ray WA, McAllister CB, Jacqz E, Wilkinson GR, Branch RA (1985) Interethnic differences in genetic polymorphism of debrisoquin and mephenytoin hydroxylation between Japanese and Caucasian populations. Clin Pharmacol Ther 38:402-408

127. Bailey DG, Dresser G, Arnold JM (2013) Grapefruit-medication interactions: forbidden fruit or avoidable consequences? Can Med Assoc J 185:309-316. https://doi.org/10.1503/ cmaj.120951

128. Bosron WF, Li TK, Vallee BL (1979) Heterogeneity and new molecular forms of human liver alcohol dehydrogenase. Biochem Biophys Res Commun 91:1549-1555

129. Edenberg HJ, Bosron WF (2010) Alcohol dehydrogenases. In: Guengerich FP (ed) Biotransformation. Comprehensive toxicology (McQueen CA series ed), 4th edn. Elsevier, New York, pp $111-130$

130. Orme-Johnson WH, Ziegler DM (1965) Alcohol mixed function oxidase activity of mammalian liver micoromes. Biochem Biophys Res Commun 21:78-82

131. Lieber CS, DeCarli LM (1970) Hepatic microsomal ethanol oxidizing system: in vitro chracteristics and adaptive properties in vivo. J Biol Chem 245:2505-2512

132. Coon MJ, Koop DR, Morgan ET (1983) Alcohol oxidation by isozyme 3 a of liver microsomal cytochrome P-450. Pharmacol Biochem Behavior 18:177-180

133. Ryan DE, Ramanathan L, Iida S, Thomas PE, Haniu M, Shively JE, Lieber CS, Levin W (1985) Characterization of a major form of rat hepatic microsomal cytochrome P-450 induced by isoniazid. J Biol Chem 260:6385-6393

134. Wrighton SA, Thomas PE, Ryan DE, Levin W (1987) Purification and characterization of ethanol-inducible human hepatic cytochrome P-450HL . Arch Biochem Biophys 258:292-297

135. Kunitoh S, Imaoka S, Hiroi T, Yabusaki Y, Monna T, Funae $Y$ (1997) Acetaldehyde as well as ethanol is metabolized by human CYP2E1. J Exp Pharmacol Ther 280:527-532

136. Terelius Y, Norsten-Höög C, Cronholm T, Ingelman-Sundberg M (1991) Acetaldehyde as a substrate for ethanol-inducible cytochrome P450 (CYP2E1). Biochem Biophys Res Commun 179:689-694

137. Bell-Parikh LC, Guengerich FP (1999) Kinetics of cytochrome P450 2E1-catalyzed oxidation of ethanol to acetic acid via acetaldehyde. J Biol Chem 274:23833-23840

138. Kono H, Bradford BU, Yin M, Sulik KK, Koop DR, Peters JM, Gonzalez FJ, McDonald T, Dikalova A, Kadiiska MB, Mason RP, Thurman RG (1999) CYP2E1 is not involved in early alcohol-induced liver injury. Am J Physiol 277:G1259-G1267

139. Balbo S, Hashibe M, Gundy S, Brennan P, Canova C, Simonato L, Merletti F, Richiardi L, Agudo A, Castellsague X, Znaor A, Talamini R, Bencko V, Holcatova I, Wang M, Hecht SS, Boffetta $\mathrm{P}(2008) N^{2}$-Ethyldeoxyguanosine as a potential biomarker for assessing effects of alcohol consumption on DNA. Cancer Epidemiol Biomark Prev 17:3026-3032

140. Guengerich FP (2020) Cytochrome P450 2E1 and its roles in disease. Chem Biol Interact 322:109056. https://doi.org/10.1016/j. cbi.2020.109056

141. Nelson SD (1982) Metabolic activation and drug toxicity. J Med Chem 25:753-765
142. Guengerich FP (2001) Common and uncommon cytochrome $\mathrm{P} 450$ reactions related to metabolism and chemical toxicity. Chem Res Toxicol 14:611-650

143. Driscoll JP, Sadlowski CM, Shah NR, Feula A (2020) Metabolism and bioactivation: it's time to expect the unexpected. J Med Chem. https://doi.org/10.1021/acs.jmedchem.0c00026

144. Cerny MA, Kalgutkar AS, Obach RS, Sharma R, Spracklin DK, Walker GS (2020) Effective application of metabolite profiling in drug design and discovery. J Med Chem. https://doi.org/10.1021/ acs.jmedchem.9b01840

145. Dalvie DK, Kalgutkar AS, Khojasteh-Bakht SC, Obach RS, O'Donnell JP (2002) Biotransformation reactions of fivemembered aromatic heterocyclic rings. Chem Res Toxicol 15:269-299

146. Kalgutkar AS, Soglia JR (2005) Minimising the potential for metabolic activation in drug discovery. Expert Opin Drug Metab Toxicol 1:91-141

147. Stepan AF, Walker DP, Bauman J, Price DA, Baillie TA, Kalgutkar AS, Aleo MD (2011) Structural alert/reactive metabolite concept as applied in medicinal chemistry to mitigate the risk of idiosyncratic drug toxicity: a perspective based on the critical examination of trends in the top 200 drugs marketed in the United States. Chem Res Toxicol 24:1345-1410. https://doi. org/10.1021/tx200168d

148. Beaune P, Dansette PM, Mansuy D, Kiffel L, Finck M, Amar C, Leroux JP, Homberg JC (1987) Human anti-endoplasmic reticulum autoantibodies appearing in a drug-induced hepatitis are directed against a human liver cytochrome P-450 that hydroxylates the drug. Proc Natl Acad Sci USA 84:551-555

149. Dansette PM, Bertho G, Mansuy D (2005) First evidence that cytochrome P450 may catalyze both $S$-oxidation and epoxidation of thiophene derivatives. Biochem Biophys Res Commun 338:450-455

150. Lecoeur S, Bonierbale E, Challine D, Gautier JC, Valadon P, Dansette PM, Catinot R, Ballet F, Mansuy D, Beaune PH (1994) Specificity of in vitro covalent binding of tienilic acid metabolites to human liver microsomes in relationship to the type of hepatotoxicity: comparison with two directly hepatotoxic drugs. Chem Res Toxicol 7:434-442

151. Beaune P, Pessayre D, Dansette P, Mansuy D, Manns M (1994) Autoantibodies against cytochromes P450: role in human diseases. Adv Pharmacol 30:199-245

152. Dansette PM, Bonierbale E, Minoletti C, Beaune PH, Pessayre D, Mansuy D (1998) Drug-induced immunotoxicity. Eur J Drug Metab Pharmacokinet 23:443-451. https://doi.org/10.1007/ BF03189993

153. Munns AJ, DeVoss JJ, Hooper WD, Dickinson RG, Gillam EMJ (1997) Bioactivation of phenytoin by human cytochrome P450: characterization of the mechanism and targets of covalent adduct formation. Chem Res Toxicol 10:1049-1058

154. Bourdi M, Larrey D, Nataf J, Berunau J, Pessayre D, Iwasaki M, Guengerich FP, Beaune PH (1990) A new anti-liver endoplasmic reticulum antibody directed against human cytochrome P-450 IA2: a specific marker of dihydralazine-induced hepatitis. J Clin Invest 85:1967-1973

155. Manns MP, Griffin KJ, Quattrochi LC, Sacher M, Thaler H, Tukey RH, Johnson EF (1990) Identification of cytochrome P450IA2 as a human autoantigen. Arch Biochem Biophys 280:229-232

156. Manns MP, Johnson EF, Griffin KJ, Tan EM, Sullivan KF (1989) Major antigen of liver kidney microsomal autoantibodies in idiopathic autoimmune hepatitis is cytochrome $\mathrm{P} 450_{\mathrm{db} 1}$. J Clin Invest 83:1066-1072

157. Eliasson E, Kenna JG (1996) Cytochrome P450 2E1 is a cell surface autoantigen in halothane hepatitis. Mol Pharmacol 50:573-582 
158. Bourdi M, Chen W, Peter RM, Martin JL, Buters JTM, Nelson SD, Pohl LR (1996) Human cytochrome P450 2E1 is a major autoantigen associated with halothane hepatitis. Chem Res Toxicol 9:1159-1166

159. Hoet P, Graf MLM, Bourdi M, Pohl LR, Chen W, Peter RM, Nelson SD, Verliinden N, Lison D (1997) Epidemic of liver disease caused by hydrochlorofluorocarbons used as ozone-sparing substitutes of chlorofluorocarbons. Lancet 350:556-558

160. Leeder JS, Riley RJ, Cook VA, Spielberg SP (1992) Human anticytochrome $\mathrm{P} 450$ antibodies in aromatic anticonvulsant-induced hypersensitivity reactions. J Exp Pharmacol Ther 263:360-367

161. Leeder JS, Gaedigk A, Lu X, Cook VA (1996) Epitope mapping studies with human anti-cytochrome P450 3A antibodies. Mol Pharmacol 49:234-243

162. Illing PT, Vivian JP, Dudek NL, Kostenko L, Chen Z, Bharadwaj M, Miles JJ, Kjer-Nielsen L, Gras S, Williamson NA, Burrows SR, Purcell AW, Rossjohn J, McCluskey J (2012) Immune selfreactivity triggered by drug-modified HLA-peptide repertoire. Nature 486:554-558. https://doi.org/10.1038/nature11147

163. Reinherz EL (2012) Pharmacology: a false sense of non-self. Nature 486:479-481. https://doi.org/10.1038/486479a

164. Montané E, Arellano AL, Sanz Y, Roca J, Farre M (2018) Drugrelated deaths in hospital inpatients: a retrospective cohort study. Br J Clin Pharmacol 84:542-552. https://doi.org/10.1111/ bcp. 13471

165. Guengerich FP (2014) Cytochrome P450-mediated drug interactions and cardiovascular toxicity: the Seldane to Allegra transformation. In: Wang J, Urban L (eds) Predictive ADMET: integrated approaches in drug discovery and development, 1st edn. Wiley, New York, pp 523-534

166. Kivistö KT, Neuvonen PJ, Klotz U (1994) Inhibition of terfenadine metabolism: pharmacokinetic and pharmacodynamic consequences. Clin Pharmacokinet 27:1-5

167. Honig PK, Wortham DC, Zamani K, Conner DP, Mullin JC, Cantilena LR (1993) Terfenadine-ketoconazole interaction: pharmacokinetic and electrocardiographic consequences. J Am Med Assoc 269:1513-1518

168. Bailey DG, Spence JD, Munoz C, Arnold JMO (1991) Interactions of citrus juices with felodipine and nifedipine. Lancet 337:251-272

169. Guengerich FP, Brian WR, Iwasaki M, Sari MA, Baarnhielm C, Berntsson P (1991) Oxidation of dihydropyridine calcium channel blockers and analogues by human liver cytochrome P-450 IIIA4. J Med Chem 34:1838-1844

170. Paine MF, Criss AB, Watkins PB (2004) Two major grapefruit juice components differ in time to onset of intestinal CYP3A4 inhibition. J Exp Pharmacol Ther 312:1151-1160. https://doi. org/10.1124/jpet.104.076836

171. Lin HL, Kenaan C, Hollenberg PF (2012) Identification of the residue in human CYP3A4 that is covalently modified by bergamottin and the reactive intermediate that contributes to the grapefruit juice effect. Drug Metab Dispos 40:998-1006. https ://doi.org/10.1124/dmd.112.044560

172. He K, Iyer R, Hayes RN, Sinz MW, Woolf TF, Hollenberg PF (1998) Inactivation of cytochrome P450 3A4 by bergamottin, a component of grapefruit juice. Chem Res Toxicol 11:252-259

173. Bailey DG, Arnold JMO, Munoz C, Spence JD (1993) Grapefruit juice-felodipine interaction: mechanism, predictability, and effect of naringin. Clin Pharmacol Ther 53:637-642

174. Bailey DG, Arnold JMO, Bend JR, Tran LT, Spence JD (1995) Grapefruit juice-felodipine interaction: reproducibility and characterization with the extended release drug formulation. Br J Clin Pharmacol 40:135-140

175. Lilja JJ, Kivistö KT, Neuvonen PJ (1999) Grapefruit juice increases serum concentrations of atorvastatin and has no effect on pravastatin. Clin Pharmacol Ther 66:118-127
176. Reimers D, Jezek A (1971) Rifampicin und andere Antituberkulotika bei gleichzeitiger oraler Kontrzeption. Przx Pneumolonol 25:255-262

177. Nocke-Finck L, Brewer H, Reimers D (1973) Wirkung von Rifampicin auf den Menstruationszyklus und die Östrogenausscheidung bei Einnahme oraler Kontrazeptiva. Dtsch Med Wochenschr 98:1521-1523

178. Guengerich FP (1988) Oxidation of $17 \alpha$-ethynylestradiol by human liver cytochrome P-450. Mol Pharmacol 33:500-508

179. Murphy PA, Kern SE, Stanczyk FZ, Westhoff CL (2005) Interaction of St. John's wort with oral contraceptives: effects on the pharmacokinetics of norethindrone and ethinyl estradiol, ovarian activity and breakthrough bleeding. Contraception 71:402-408

180. Moore LG, Goodwin B, Jones SA, Wisely GB, Serabjit-Singh CJ, Wilson TM, Collins JL, Kliewer SA (2000) St. John's wort induces hepatic drug metabolism through activation of the pregnane X receptor. Proc Natl Acad Sci USA 97:7500-7502

181. Kirchheiner J, Nickchen K, Bauer M, Wong ML, Licinio J, Roots I, Brockmöller J (2004) Pharmacogenetics of antidepressants and antipsychotics: the contribution of allelic variations to the phenotype of drug response. Mol Psychiatry 9:442-473. https://doi. org/10.1038/sj.mp.4001494

182. Greenblatt DJ, Venkatakrishnan K, Harmatz JS, Parent SJ, von Moltke LL (2010) Sources of variability in ketoconazole inhibition of human cytochrome P450 3A in vitro. Xenobiotica 40:713-720. https://doi.org/10.3109/00498254.2010.506224

183. Zimmerlin A, Trunzer M, Faller B (2011) CYP3A time-dependent inhibition risk assessment validated with 400 reference drugs. Drug Metab Dispos 39:1039-1046. https://doi.org/10.1124/ dmd.110.037911

184. Eng H, Tseng E, Lin J, Goosen TC, Cerny MA, Obach RS (2019) Delineation of in vitro cut-off values for CYP3A4/5 time-dependent inhibiton useful in early drug design — a side-by-side comarison in human liver microsomes and hepatocytes. In: Abstracts, 12th International Int Soc Study Xenobiotics meeting, Portland, OR, July

185. Guengerich FP (2015) Human cytochrome P450 enzymes. In: Ortiz de Montellano PR (ed) Cytochrome P450: structure, mechanism, and biochemistry, vol 2, 4th edn. Springer, New York, pp 523-785

186. Guengerich FP (2020) Cytochrome P450 catalysis in natural product biosynthesis. In: Bollinger M, Booker S, Bandarian V (eds) Comprehensive natural products, III: chemistry and biology, radicals and metalloenzymology, 5th edn. Elsevier, New York

187. Rendic S, Guengerich FP (2018) Human cytochrome P450 enzymes 5-51 as targets of drugs, natural, and environmental compounds: mechanisms, induction, and inhibition-toxic effects and benefits. Drug Metab Rev 50:256-342

188. Zhang D, Flint O, Wang L, Gupta A, Westhouse RA, Zhao W, Raghavan N, Caceres-Cortes J, Marathe P, Shen G, Zhang Y, Allentoff A, Josephs J, Gan J, Borzilleri R, Humphreys WG (2012) Cytochrome P450 11A1 bioactivation of a kinase inhibitor in rats: use of radioprofiling, modulation of metabolism, and adrenocortical cell lines to evaluate adrenal toxicity. Chem Res Toxicol 25:556-571. https://doi.org/10.1021/tx200524d

189. Mast N, Norcross R, Andersson U, Shou M, Nakayama K, Bjorkhem I, Pikuleva IA (2003) Broad substrate specificity of human cytochrome P450 46A1 which initiates cholesterol degradation in the brain. Biochemistry 42:14284-14292

190. Mast N, Anderson KW, Johnson KM, Phan TTN, Guengerich FP, Pikuleva IA (2017) In vitro cytochrome P450 46A1 (CYP46A1) activation by neuroactive compounds. J Biol Chem 292:1293412946. https://doi.org/10.1074/jbc.M117.794909

191. Jewell SA, Bellomo G, Thor H, Orrenius S, Smith MT (1982) Bleb formation in hepatocytes during drug metabolism is caused 
by disturbances in thiol and calcium ion homeostasis. Science 217:1257-1259

192. Farber JL (1990) The role of calcium in lethal cell injury. Chem Res Toxicol 3:503-508

193. Lehman-McKeeman LD (2019) Mechanisms of toxicity. In: Klaassen CD (ed) Casarett and Doull's toxicology: the basic science of poisons, 3rd edn. pp 65-125

194. Thompson RA, Isin EM, Li Y, Weidolf L, Page K, Wilson I, Swallow S, Middleton B, Stahl S, Foster AJ, Dolgos H, Weaver R, Kenna JG (2012) In vitro approach to assess the potential for risk of idiosyncratic adverse reactions caused by candidate drugs. Chem Res Toxicol 25:1616-1632. https://doi.org/10.1021/tx300 091x

195. Thompson RA, Isin EM, Ogese MO, Mettetal JT, Williams DP (2016) Reactive metabolites: current and emerging risk and hazard assessments. Chem Res Toxicol 29:505-533. https://doi. org/10.1021/acs.chemrestox.5b00410

196. Edwards SW, Tan Y-M, Villeneuve DL, Meek ME, McQueen CA (2016) Adverse outcome pathways-organizing toxicological information to improve decision making. J Exp Pharmacol Ther 356:170-181. https://doi.org/10.1124/jpet.115.228239

197. Weaver RJ, Blomme EA, Chadwick AE, Copple IM, Gerets HHJ, Goldring CE, Guillouzo A, Hewitt PG, Ingelman-Sundberg M, Jensen KG, Juhila S, Klingmuller U, Labbe G, Liguori MJ, Lovatt CA, Morgan P, Naisbitt DJ, Pieters RHH, Snoeys J, van de Water B, Williams DP, Park BK (2020) Managing the challenge of drug-induced liver injury: a roadmap for the development and deployment of preclinical predictive models. Nat Rev Drug Discov 19:131-148. https://doi.org/10.1038/s41573-019-0048-x

198. Rana P, Aleo MD, Gosink M, Will Y (2019) Evaluation of in vitro mitochondrial toxicity assays and physicochemical properties for prediction of organ toxicity using 228 pharmaceutical drugs. Chem Res Toxicol 32:156-167. https://doi.org/10.1021/ acs.chemrestox.8b00246

199. Aleo MD, Shah F, Allen S, Barton HA, Costales C, Lazzaro S, Leung L, Nilson A, Obach RS, Rodrigues AD, Will Y (2020) Moving beyond binary predictions of human drug-induced liver injury (DILI) toward contrasting relative risk potential. Chem Res Toxicol 33:223-238. https://doi.org/10.1021/acs.chemrestox $.9 \mathrm{~b} 00262$

200. Weaver RJ, Valentin JP (2019) Today's challenges to de-risk and predict drug safety in human "Mind-the-Gap". Toxicol Sci 167:307-321. https://doi.org/10.1093/toxsci/kfy270
201. Hsieh JH, Smith-Roe SL, Huang R, Sedykh A, Shockley KR, Auerbach SS, Merrick BA, Xia M, Tice RR, Witt KL (2019) Identifying compounds with genotoxicity potential using Tox 21 high-throughput screening assays. Chem Res Toxicol 32:13841401. https://doi.org/10.1021/acs.chemrestox.9b00053

202. Fink-Gremmels J (2008) Implications of hepatic cytochrome P450-related biotransformation processes in veterinary sciences. Eur J Pharmacol 585:502-509. https://doi.org/10.1016/j.ejpha r.2008.03.013

203. Aidasani D, Zaya MJ, Malpas PB, Locuson CW (2008) In vitro drug-drug interaction screens for canine veterinary medicines: evaluation of cytochrome P450 reversible inhibition. Drug Metab Dispos 36:1512-1518

204. Knych HK, Baden RW, Gretler SR, McKemie DS (2019) Characterization of the in vitro CYP450 mediated metabolism of the polymorphic CYP2D6 probe drug codeine in horses. Biochem Pharmacol 168:184-192. https://doi.org/10.1016/j. bcp.2019.07.005

205. Shin YG, Le H, Khojasteh C, Hop CE (2011) Comparison of metabolic soft spot predictions of CYP3A4, CYP2C9 and CYP2D6 substrates using MetaSite and StarDrop. Comb Chem High Throughput Screen 14:811-823

206. Trunzer M, Faller B, Zimmerlin A (2009) Metabolic soft spot identification and compound optimization in early discovery phases using MetaSite and LC-MS/MS validation. J Med Chem 52:329-335. https://doi.org/10.1021/jm8008663

207. Cruciani G, Carosati E, De Boeck B, Ethirajulu K, Mackie C, Howe T, Vianello R (2005) MetaSite: understanding metabolism in human cytochromes from the perspective of the chemist. $\mathrm{J}$ Med Chem 48:6970-6979

208. Cunningham AR, Cunningham SL, Rosenkranz HS (2004) Structure-activity approach to the identification of environmental estrogens: the MCASE approach. SAR QSAR Environ Res 15:55-67. https://doi.org/10.1080/1062936032000169679

209. Mayer J, Cheeseman MA, Twaroski ML (2008) Structure-activity relationship analysis tools: validation and applicability in predicting carcinogens. Regul Toxicol Pharmacol 50:50-58. https://doi. org/10.1016/j.yrtph.2007.09.005

210. Dearden JC (2003) In silico prediction of drug toxicity. J Comput Aided Mol Des 17:119-127 